\title{
The Economic Dialogues with the ECOFIN Council and the Eurogroup
}

The euro crisis re-affirmed the centrality of intergovernmental institutions in EMU decision-making (Csehi and Puetter 2021; Fabbrini 2016; Maricut and Puetter 2018). Next to the European Council - the EU's highest political body - the main actors in the field were the ECOFIN Council and the Eurogroup. Both Council configurations comprise economic and finance ministers, either from all Member States (for ECOFIN) or just from Eurozone countries (for the Eurogroup). Since their portfolio is crucial for a country's economic performance, finance ministers are typically among the highest-ranked members in a cabinet at the national level. In the EU institutional setting, ECOFIN is one of the oldest and most influential Council configurations, with a legal mandate and lead role in EU economic governance since the Maastricht Treaty (Puetter 2014: 155). The Eurogroup functioned outside the Treaty framework from 1998 until 2009, when it was recognised as an informal EU body with a fixed-term president (Protocol 14 TFEU). While both institutions have competences in economic policy coordination, the Eurogroup is the more powerful actor (among others) because it decides on financial assistance programmes that are part of the ESM (ESM Treaty, Article 5). Nowadays, the activities of the two Council configurations are distinct, although ECOFIN has to formally endorse Eurogroup decisions in order to give them legal power (Pisani-Ferry 2006; Puetter 2006).

Owing to their broad mandates and centrality in EMU decision-making during the crisis, the ECOFIN Council and the Eurogroup raise serious accountability concerns (Braun and Hübner 2019; Craig 2017). However, unlike the ECB and the Commission (discussed in the previous chapters), the two intergovernmental bodies have fewer accountability obligations towards the EP. In line with the Treaties, Council bodies are democratically accountable 'to their [own] national parliaments, or to their citizens' (Article $10(2)$ TEU). As a result, the EP does not have legal mechanisms to sanction 
EU intergovernmental institutions for their performance - as opposed to procedures for dismissing the Chair of the Supervisory Board of the ECB (see Chapter 4.2) or passing a motion of censure against the Commission (Chapter 5.2). At the same time, national parliaments and electorates can only hold their own governments accountable, not the ECOFIN Council or the Eurogroup as a whole. There is thus a structural flaw in the EU political system that creates an accountability void for intergovernmental bodies: to put it simply, ministers are individually but not collectively accountable for EU decisions (cf. Brandsma et al. 2016: 624-625). As the only directly elected institution at the EU level, the EP could technically act as the appropriate forum responsible for overseeing collective decision-making by national governments. In fact, the introduction of the Economic Dialogues in the context of the euro crisis acknowledged the need to increase parliamentary scrutiny of EU executive actors, asking the ECOFIN Council and the Eurogroup to appear regularly before the EP's ECON Committee (Chapter 2.2.2).

This chapter examines how MEPs oversee the ECOFIN Council and the Eurogroup in the practice of the Economic Dialogues. Organised since 2012 at the ECON Committee, the Economic Dialogues bring MEPs face to face with the incumbent minister of the ECOFIN Council Presidency on the one hand and the Eurogroup President on the other. While the set-up of Economic Dialogues is similar to meetings with the Commission, the topics discussed and the political dynamic are substantially different. Often, MEPs use Economic Dialogues with ECOFIN to ask about the status of ongoing legislative files, while meetings with the Eurogroup President revolve around financial assistance programmes. Despite the original purpose of Economic Dialogues to ensure EP scrutiny of the European Semester, the emphasis is only partially visible in meetings with the Eurogroup President and almost completely absent from Dialogues with the ECOFIN Council. Moreover, parliamentary questions addressed to the Eurogroup President are both more intense and more relevant to the activity of the Eurogroup as an executive body than the questions posed to the ECOFIN Council Presidency. In fact, in line with the scenarios of legislation oversight outlined in Chapter 3.3.1, the EP's relationship with the Eurogroup qualifies as 'Answerability', whereas the interactions with the ECOFIN Council fall in-between 'Transparency' and 'No control'.

The chapter starts by describing the roles of the ECOFIN Council and the Eurogroup in the EMU governance architecture as well as their centrality during the crisis. The second section problematises the key accountability issues of the two bodies, with an emphasis on their (lack of) accountability towards the EP. Next, the chapter discusses the Economic Dialogues with 
ECOFIN and Eurogroup separately. Since the meetings take place at different times and deal with varying topics, it makes sense to present them independently from each other. In fact, the two types of Economic Dialogues help show the contrast in mandates between ECOFIN and Eurogroup, despite their overlap in composition - as Eurozone finance ministers are part of both institutions. The conclusion reflects on the findings in line with the theoretical expectations set in Chapter 3.3.2.

\subsection{BACKGROUND: ECOFIN, EUROGROUP, AND THE POLITICAL} ACCOUNTABILITY OF INTERGOVERNMENTAL ACTORS IN THE EMU

The ECOFIN Council has had clear responsibilities in EU economic governance since the Maastricht Treaty. Nowadays, Article 121 TFEU specifies the role of ECOFIN in deciding the BEPGs, monitoring economic developments through multi-lateral surveillance, and providing recommendations to Member States depending on their performance and compliance with the BEPGs. In the early zooos, ECOFIN took charge of the Lisbon Agenda and later the Europe 2020 Strategy for growth and jobs (from 2010), becoming the 'dominant political institution' in EU socio-economic policy coordination (Puetter 2014: 161). Starting in 2005, the ECOFIN Council combined the BEPGs with Employment Guidelines into the streamlined 'Integrated Guidelines', which additionally allowed the issuing of CSRs to governments facing specific challenges (Deroose et al. 2008: 836-837). After the crisis, ECOFIN continued to play a key role in economic and social policy coordination in the reformed governance framework of the European Semester (Maricut and Puetter 2018; see below).

Next to economic policy coordination, the ECOFIN Council covers issues related to taxation, financial markets, and capital movements, as well as EU external relations (Council of the European Union 2020a). Similar to other Council configurations, ECOFIN produces legislative acts (regulations, directives, and decisions), often in cooperation with the EP in the ordinary or special legislative procedures, and non-legislative acts such as joint actions and common positions (Lewis 2019: 164). Every six months, the rotating Council Presidency sets ECOFIN priorities - which are especially visible on the legislative front. In terms of external relations, ECOFIN seeks to coordinate the positioning of Member States in international organisations such as the IMF, the World Bank, or the Organisation for Economic Co-operation and Development (Gstöhl 2008).

Furthermore, the ECOFIN Council has competences in the EDP (Article 126 TFEU) as the ultimate decision-maker on whether a government has 
breached EU budget deficit rules and deserves sanctions. As mentioned in Chapter 2.1, sanctions were never applied before the Lisbon Treaty because large Member States such as France and Germany could not be outvoted in ECOFIN (Collignon 2004; Schuknecht et al. 2011: 10). After the crisis, voting rules were modified in order to allow an easier application of sanctions. However, the only instance of penalties ever being imposed on a Member State concerns Spain in 2015; even then, the fine was imposed for failure to provide accurate statistics to the Commission rather than for breaking EDP debt and deficit rules (Savage and Howarth 2018: 213). In 2016, ECOFIN voted that Spain and Portugal had not taken effective measures to correct their excessive deficits, a decision which would normally trigger sanctions under the EDP (Council of the European Union 2016). In the end, however, the Commission chose not to impose a fine given the 'exceptional economic circumstances' in the two countries (Sacher 2019).

While formal votes on the EDP take place in the ECOFIN Council, cases including Eurozone economies are previously agreed in the Eurogroup. With the launch of the Stability and Growth Pact (1997) and the last stage of the EMU (1998), Member States saw an increased need for closer economic and fiscal policy coordination among economies sharing the common currency. In this context, the French demanded a political counterweight to the ECB (a 'gouvernementéconomique'), and the ECOFIN Council was considered insufficient for the task (Howarth 2007). The Eurogroup was the compromise solution: an informal body functioning outside the EU framework, focused on facilitating close interactions between Eurozone finance ministers, while keeping out governments who opted out of the EMU - such as the UK, Denmark, and Sweden (Puetter 2oo6: 61). Over time, the Eurogroup evolved from 'semi-clandestinity to half-light' as an informal Council caucus in charge of implementing the most significant aspects of the SGP (Pisani-Ferry 2006: 840). After the 2005 reform of the SGP, the Eurogroup was tasked with strengthening the fiscal surveillance of Eurozone Member States by closely assessing their annual national budgets (Hodson 2011: 40-41). With the Lisbon Treaty, the Eurogroup was formally incorporated into the EU institutional framework and assigned the objective to "promote conditions for stronger economic growth' and 'to that end, to develop ever-closer coordination of economic policies within the euro area' (Article 137 and Protocol 14 TFEU).

From the start, the uniqueness of the Eurogroup came from its working methods, which included several features (Puetter 2004: 857-858). The first was informality, which meant that the decisions taken were not official until endorsed by the ECOFIN Council; however, an agreement at the Eurogroup level could not be reversed because it signalled approval by a majority of the 
ECOFIN Council. The second feature referred to its restricted participation; unlike formal Council meetings, where country ambassadors and other officials were present, the Eurogroup deliberately chose to have few people in the room, following a 'minister-plus-one' formula. Third, all Eurogroup debates were strictly confidential, that is, there were no minutes, conclusions, or public votes as in regular Council meetings (cf. Puetter 2006: chapter 3). The latest version of the Eurogroup's working methods dates from 2008, when ministers reiterated their commitment to flexibility/pragmatism and confidentiality as part of the decision-making process (Eurogroup 2008). Overall, informality and secrecy were seen to encourage frank exchanges between ministers and decisions taken by consensus in a form of 'deliberative intergovernmentalism' (Puetter 2012, 2014).

From a legal perspective, the informality of the Eurogroup is a matter of controversy. Despite its significant powers in EU economic governance, the Eurogroup is still not a formal EU institution which can be held liable for its decisions. According to a recent judgment of the CJEU, the Eurogroup 'cannot be equated with a configuration of the Council', 'does not have any competence of its own', and is not 'capable of giving rise to non-contractual liability of the European Union' (Court of Justice of the European Union 2020: 2). The judgment is important because it closes the door for legal accountability through national and EU courts, making the political scrutiny of the Eurogroup all the more relevant.

Between 1998 and 2009, the Eurogroup kept a low profile in the EU governance architecture. This changed with the onset of the euro crisis, which brought the institution to the centre of EMU decision-making while also expanding the scope of the ECOFIN Council portfolio. The following pages describe the main developments involving the two institutions.

\subsubsection{The Euro Crisis and the Domination of Intergovernmental Bodies}

The euro crisis required immediate and decisive executive action at the $\mathrm{EU}$ level, but the institutional framework was not geared towards emergency politics (Kreuder-Sonnen 2019: chapter 5). Although the Eurogroup and the ECOFIN Council were propelled into action, they lacked the political authority to make credible pledges of financial assistance (Puetter 2012: 171). In this context, heads of state and government in the European Council took the lead in crisis management and provided the outlines of the most important reforms (Van Kemseke 2014; Van Rompuy 2014). For Eurozone Member States, a special European Council formation was institutionalised - the 
Euro Summits (Council of the European Union 2019). Yet although the heads of state and government were instrumental in setting the tone for the $\mathrm{EU}$ response to the crisis, finance ministers remained in charge of specialised decisions within the Eurogroup and the ECOFIN Council. Keeping with the rapid pace of the crisis, finance ministers intensified the frequency of their meetings: for example, in the period 2010-2015, the Eurogroup met eightynine times, while ECOFIN held eighty-one meetings (Maricut and Puetter 2018: 201). This means that finance ministers met on average more than once a month.

Both Council configurations saw their activities increase during the crisis. In the early days, ECOFIN ministers extended the practice of 'informal breakfasts' to longer, livelier meetings where they exchanged views on crisis measures (Puetter 2014: 163). In terms of legislative reforms (see Chapter 2.1.1), the ECOFIN Council formalised quick agreements on the Six-Pack (2011), the Two-Pack (2013), and the SSM Regulation (2013). Once the European Semester was established as the new framework for economic policy coordination, ECOFIN engaged in substantive discussions on different instruments such as the AGS or CSRs; however, debates moved over time to preparatory bodies such as the Economic Policy Committee (EPC) or the EFC (Maricut and Puetter 2018: 203). In this context, the ECOFIN Council 'machinery' had to get used to the increased roles of the Commission and the Employment, Social Policy, Health and Consumer Affairs Council (EPSCO Council) in decision-making over the European Semester (Zeitlin and Vanhercke 2018). In parallel, the post-crisis decade (2010-2020) brought more legislative proposals to the ECOFIN Council agenda on issues such as taxation (General Secretariat of the Council 2019a) and financial services (General Secretariat of the Council 2019b). These are complicated files for which ministers needed years to find agreement - if that happened at all.

For its part, the Eurogroup became the centre of decision-making on all aspects related to financial assistance programmes and conditionality negotiations. Members of its main preparatory body - the Eurogroup Working Group (EWG) - sat on the Board of Directors of the temporary European Financial Stability Facility (EFSF) from 2010 to 2012 (European Stability Mechanism 2020a). After the ESM was established as a permanent institution outside the EU framework, Eurozone finance ministers became the Board of Governors of the ESM, while the Eurogroup President served as its Chair (ESM Treaty, Article 5). The practical administration and monitoring of programme countries fell to the 'Troika' - an informal alliance comprising the European Commission, the ECB, and the IMF (European Stability Mechanism 2019: 77). Among the public, the Troika was often considered the face of bailouts and 
austerity measures in the euro crisis; in practice, it was the Eurogroup which brokered agreements and supervised the implementation of aid packages (Craig 2017: 237; Dijsselbloem 2014). This meant that Eurozone finance ministers decided if and how much financial assistance a country received, as well as whether governments fulfilled their obligations for the loans. The interactions between the Eurogroup and the Troika have been compared to a principalagent relationship, where Eurozone finance ministers give a mandate to the Troika to negotiate the conditions of a loan on their behalf and then monitor its implementation (Braun and Hübner 2019: 14). In this respect, the power of the Eurogroup was cemented in the early days of the crisis when the Euro Summit specified that 'any disbursement on the bilateral loans would be decided by the euro area Member States by unanimity' (Euro Summit 2010).

While financial assistance formed the core business of the Eurogroup during the crisis (Hodson and Puetter 2016), there were other activities in the ministers' portfolio. As visible from its biannual work programmes, the Eurogroup has kept a constant interest in the European Semester in respect of assessing DBPs of Eurozone countries, monitoring their Medium-Term Objectives, and evaluating the implementation of the EDP (e.g. Eurogroup 2014, 2018). Eurogroup ministers also focus on the economic situation in the Eurozone as a whole and issue general euro area recommendations (Braun and Hübner 2019: 26). At the level of preparatory bodies, euro area recommendations are the responsibility of the EWG, while economic CSRs are discussed by EFC Alternates and the EPC (Maricut and Puetter 2018: 204). Furthermore, the Eurogroup President was closely involved in designing the post-crisis economic governance framework, having participated in the Four Presidents' Report (Van Rompuy 2012) and the Five Presidents' Report (2015). On the legislative front, the Eurogroup paid special attention to the completion of the banking union and its policy implications for the Eurozone (Eurogroup 2013). Last but not least, with the institutionalisation of Euro Summits, the Eurogroup became responsible for preparing the meetings of Eurozone heads of state and government as well as following up on their conclusions (Council of the European Union 2020b).

Overall, the euro crisis empowered both ECOFIN and the Eurogroup in the economic and financial framework of the EMU. This empowerment came at the cost of political accountability, as discussed below.

\subsection{THE ACCOUNTABILITY OF INTERGOVERNMENTAL BODIES: KEY ISSUES}

The political accountability of intergovernmental bodies is structurally complicated in the EU (see Chapter 2.2.1). In theory, each national government is 
accountable to its own parliament and electorate for decisions taken at the EU level (Article $10 \mathrm{TEU}$ ). Yet intergovernmental agreements are collective, making it difficult for national parliaments or voters to control the outcome of EU decision-making in the absence of unanimity rules (Brandsma et al. 2016: 625; see also Crum and Curtin 2015). The most blatant example is the referendum on a new financial assistance programme for Greece, organised by the Tsipras government in mid-2015. While the referendum had clear populist motivations, asking the Greek people to "say "no" to ultimatums, "no" to blackmail', the vote did not change the outcome of intergovernmental negotiations - as Greek Prime Minister Alexis Tsipras accepted a week later the same if not heavier conditions attached to financial assistance (Lowen 2015). Former Italian Prime Minister Mario Monti described the referendum as a violation of democracy' because it seemingly offered the Greek voters a choice and then 'threw it away' (cited in Vincenti and Michalopoulos 2015). In Monti's view, the culprit was Tsipras, not the $\mathrm{EU}$, yet the problem is systemic: national electorates can vote governments in and out of office, but they have little control over what is decided at the EU level, even when they give cabinets unambiguous mandates in Council negotiations.

The other major issue of intergovernmental bodies concerned how equal Member States were in negotiations. Despite constitutional provisions regarding the 'equality of Member States before the Treaties' (Article 4[2] TEU), the dynamics of the euro crisis inevitably created a hierarchical relationship between creditor and debtor countries (Crum and Merlo 2020; Fabbrini 2016). This made accountability difficult because it allowed, de facto, for some national parliaments and electorates to have more control over EU decision-making than others. Germany in particular was an important player in its capacity as the Eurozone's largest and strongest economy as well as the only country whose national parliament had to vote on ESM lending programmes both ex ante and ex post (Moschella 2017: 241). In addition, Germany's influence was ideational, shaping the post-crisis economic governance architecture based on its national model of 'stability through balanced budgets', with clear deficit rules and targets (Schmidt 2020: 127). Wolfgang Schäuble, the German finance minister (2009-2017) in ECOFIN and the Eurogroup, remained a divisive figure throughout the crisis: vilified in Greece as an advocate of austerity who imposed harsh conditions on countries in need of financial assistance while being celebrated at home for protecting taxpayers' money (Kroet and Oliveira 2015).

In the academic literature (and in reality), the idea of German domination is appealing because it makes intuitive sense. Indeed, from a rationalist perspective, we would expect the preferences of the strongest country to shape the 
outcome of EU decision-making (Schimmelfennig 2015). Nevertheless, this view overlooks the role of other 'creditor' countries that shared the philosophy of the German government on balanced budgets. Among others, the Netherlands and Finland were the most fervent supporters of austerity and structural reforms as necessary conditions for countries requesting financial assistance (Schmidt 2020: 134). Given the confidential, collegial, and consensus-seeking mode of decision-making in the Eurogroup, ministers were unlikely to speak out against each other (Puetter 2016: 6o9). When Greek Finance Minister Yanis Varoufakis broke this taboo in 2015 by publicly questioning the democratic character of secretive deliberations and criticising the treatment of his country, he only attracted hostility from the Eurogroup (Bickerton 2015). No other minister supported his position, although this could have been an opportunity to address the Eurogroup's lack of transparency and accountability to national electorates.

In fact, finance ministers generally see the Eurogroup working methods as an advantage. From their standpoint, the flexibility and confidentiality of Eurogroup meetings are assets because they allow frank discussions among peers without worrying how domestic audiences will react to their positions at the EU level. As (in-)famously explained by former Eurogroup President JeanClaude Juncker:

Monetary policy is a serious issue. We should discuss this in secret, in the Eurogroup. The same applies to economic and monetary policies in the Union. If we indicate possible decisions, we are fuelling speculations on the financial markets and we are throwing in misery mainly the people we are trying to safeguard from this. I'm ready to be insulted as being insufficiently democratic, but I want to be serious. (...) There is insufficient awareness at the European level when it comes to these issues, because each of us wants to show his domestic public that he's the greatest guy under the sky. (Juncker, cited in Pop 2011)

The problem is that the Eurogroup's informal and secret decision-making process is structurally at odds with democratic accountability and transparency (Braun and Hübner 2019; Craig 2017; Mahony 2015). While finance ministers might argue they need the 'space to think' within the EU's intergovernmental institutions, national citizens also have the right to know what positions their respective governments are taking behind closed doors (Hillebrandt and Novak 2016: 528). Unsurprisingly, the Eurogroup believes there is 'an extremely high level of governmental and parliamentary scrutiny' at the national level - even in the controversial cases of financial assistance programmes through the ESM (Dijsselbloem 2014). 
However, if national parliaments cannot hold EMU intergovernmental bodies accountable for collective decisions or are unequal in doing so, the EP is also incapable of compensating for this structural weakness. In the EMU, the EP lacks formal powers to veto or influence executive decisions of the Eurogroup and the ECOFIN Council (Crum and Merlo 2020; Rittberger 2014). From a principal-agent perspective (Chapter 3.2.1), the EP is not the principal of ECOFIN or the Eurogroup, whose ministers have a direct relationship to their domestic electorates. In fact, in relation to EU and national citizens, the EP and EU intergovernmental bodies play the role of 'multiple competing agents' (Strøm 2000: 269), similar to the dynamics found in presidential systems of government (Lupia and McCubbins 1994; McCubbins and Schwartz 1984). Going back to the Treaties, the EP and the Council are envisaged as co-legislators in the ordinary legislative procedure (Articles 289 and 294 TFEU), representing citizens and Member States, respectively, in the EU decision-making process (Article 1o TEU). If anything, the two institutions can frustrate each other's legislative and budgetary agendas and exercise a form of ex ante or pre-emptive accountability. For this reason, the new executive roles of the Eurogroup and the ECOFIN Council in financial assistance or the European Semester sit uncomfortably with the constitutional roles of the institutions prescribed in the Treaties. This is not to say that effective EP scrutiny of the ECOFIN Council and the Eurogroup is impossible, but it is difficult from the onset.

Furthermore, the EP's legislative focus and internal dynamics do not help the effective scrutiny of intergovernmental actors. The profile of the EP as a 'law-making' parliament (Sieberer 2011) with a transnational multi-party system (Russo and Wiberg 2010) is bound to limit the structural opportunities for oversight in the EMU (Ogul 1976; Rockman 1984). In EMU legislative decision-making, the EP may be on equal footing with the Council under the ordinary legislative procedure, but in practice the Council is the stronger actor (Bressanelli and Chelotti 2016, 2018). The ESM is an intergovernmental organisation outside the EU Treaty framework, meaning the EP has no influence whatsoever over financial assistance programmes (Howarth and Quaglia 2014; Rittberger 2014: 117). The only element that gave the EP an advantage over the ECOFIN Council and the Eurogroup since the euro crisis was public attention to EMU governance, especially in respect of bailout decisions. As we know from studies on legislative oversight, public pressure can be an important factor in the parliamentary scrutiny of executive actors (Martin 2011b; McCubbins and Schwartz 1984; Wiberg and Koura 1994).

Against this background, the Economic Dialogues with the ECOFIN Council and the Eurogroup President were established in the hope that they 
will improve political accountability in the EMU (de la Parra 2017; Kluger Dionigi 2020). The legal basis of the Economic Dialogues is the same as that for the Commission, including identical articles on transparency and accountability found in the Two-Pack and the Six-Pack legislation. Accordingly, the EP and the Council could organise Economic Dialogues on the BEPGs, the results of multi-lateral surveillance on budgetary positions (including the EDP) and macroeconomic imbalances, as well as on the content of CSRs - especially if there were deviations from Commission recommendations (the so-called 'comply or explain' principle). ${ }^{23}$ In respect of the Eurozone, the Six-Pack listed as possible topics the sanctions and fines applied in the enforcement of the EDP and the MIP, respectively. ${ }^{24}$ The Two-Pack added two elements to the list of potential subjects of Economic Dialogues: (1) the monitoring and assessing of budgetary plans in the Eurozone ${ }^{25}$ and (2) the special procedures for countries experiencing financial difficulties - namely enhanced surveillance, macroeconomic adjustment programmes, or postprogramme surveillance. ${ }^{26}$ In fact, according to Markakis, the Two-Pack 'lays down the most detailed accountability and transparency requirements to date' (Markakis 2020: 128). While the tasks of the ECOFIN Council and the Eurogroup are difficult to separate in the European Semester (e.g. for the EDP and the MIP), it was clear that the Eurogroup will be the interlocutor for questions on financial assistance programmes - even if the ESM was technically not an EU organisation.

Before moving to the analysis of oversight interactions between the EP and the ECOFIN Council/the Eurogroup, a few words are in order regarding the appropriateness of the type of actor 'giving account' to a parliamentary forum (cf. Bovens 2007). It is well known that finance ministers representing the Presidency of the Council still need to run their own national administrations while knowing the details of legislative and executive decisions taken by ECOFIN at the level of preparatory bodies and ministers' meetings. Under the circumstances, is it reasonable to expect the incumbent of the Presidency to be held accountable for decisions taken by ECOFIN as a whole? The format of the Economic Dialogues would suggest this is the case. The problem is less pronounced for the Eurogroup President, whose position is permanent (for two and a half years) and who chairs an informal and smaller, club-like body. In any case, both Presidents - of ECOFIN and the Eurogroup - are

23 Article zab of Regulation 1466/97, Article 2a of Regulation 1467/97, and Article 14(1) of Regulation 1176/2011.

24 Article 3 of Regulation 1173/2011 and Article 6 of Regulation 1174/2011.

25 Article 15 of Regulation 473/2013.

26 Articles 3, 7, 14, and 18 of Regulation 472/2013. 
perceived to speak on behalf of the Council and articulate the common or consensus position of the Member States in their respective configurations.

The following sections go over the content of the two types of Economic Dialogues in turn, following the analytical framework outlined in Chapter 3.3. Each section starts with an overview of the profile of questioners and respondents identified during Economic Dialogues, which is important in order to grasp political dynamics in the EP as well as differences in responsiveness between Council Presidencies or Eurogroup Presidents. Next, in line with the analytical framework of the book, the emphasis lies on the types of questions asked by MEP - which can request information, justification of conduct, change of decisions, sanctions, or policy views. Finally, the analysis includes the types of answers given in response to parliamentary questions (explicit, intermediate, or non-replies that provide rectification, justification of conduct, or equivocation/evasion of questions). The conclusion reflects on the findings of the analysis in relation to the scenarios of legislative oversight identified in Chapter 3.3.1.

\subsection{THE ECONOMIC DIALOGUES WITH THE ECOFIN COUNCIL PRESIDENCY}

The ECON Committee organises Economic Dialogues with the finance minister of the country holding the ECOFIN Council Presidency between two and four times a year. In the period under focus (January 2012-May 2019), most Presidencies attended ECON meetings at the beginning and at the end of their terms (Denmark, Cyprus, Ireland, Lithuania, Italy, Luxembourg, the Netherlands, Slovakia, Malta, Estonia, and Bulgaria), while others were present only once (Greece, Latvia, Austria, and Romania). If Greece and Romania held the Presidency during EP electoral years (2014 and 2019, respectively), it is not clear why Latvia (2015) and Austria (2018) attended Economic Dialogues only at the beginning of their terms. Keeping in mind that the Six-Pack entered into force in December 2011, the first formal Dialogue with ECOFIN took place on 23 January 2012. At the start of the meeting, the Chair of the ECON Committee described the new procedure as follows:

As you know, it's customary for the incoming president of the ECOFIN Council to come along to the committee and discuss the program and priority of the Presidency and the challenges ahead. And these exchanges of views with the president of the ECOFIN Council are also a good occasion to have an Economic Dialogue as foreseen in the new rules for economic governance 
in the Six-Pack. And in particular, on how the Council will implement the new economic governance framework, both fiscal and macroeconomic imbalances in practice. (Sharon Bowles, cited in European Parliament 2012a)

In other words, the Economic Dialogues were incorporated into an established practice of the ECON Committee to meet the incumbent Presidency of the Council to discuss priorities or achievements for the next/past six months. As the analysis below will demonstrate, this institutional origin of the Economic Dialogues with ECOFIN will prove impervious to change, as the topics covered will continue to revolve around legislative files handled by each Presidency instead of instruments of the European Semester as envisaged in the Six-Pack.

Figure 6.1 shows that the ECOFIN Council Presidency attended 26 Economic Dialogues in the period under investigation: 9 Economic Dialogues took place during the 7 th EP parliamentary term (20092014) and 17 during the 8th parliamentary term (2014-2019). In total, the analysis identified 613 questions raised by MEPs in 26 meetings organised over 7 years. On average, MEPs asked 22 questions per meeting during the 7 th parliamentary term and 25 questions per meeting during the 8 th term.

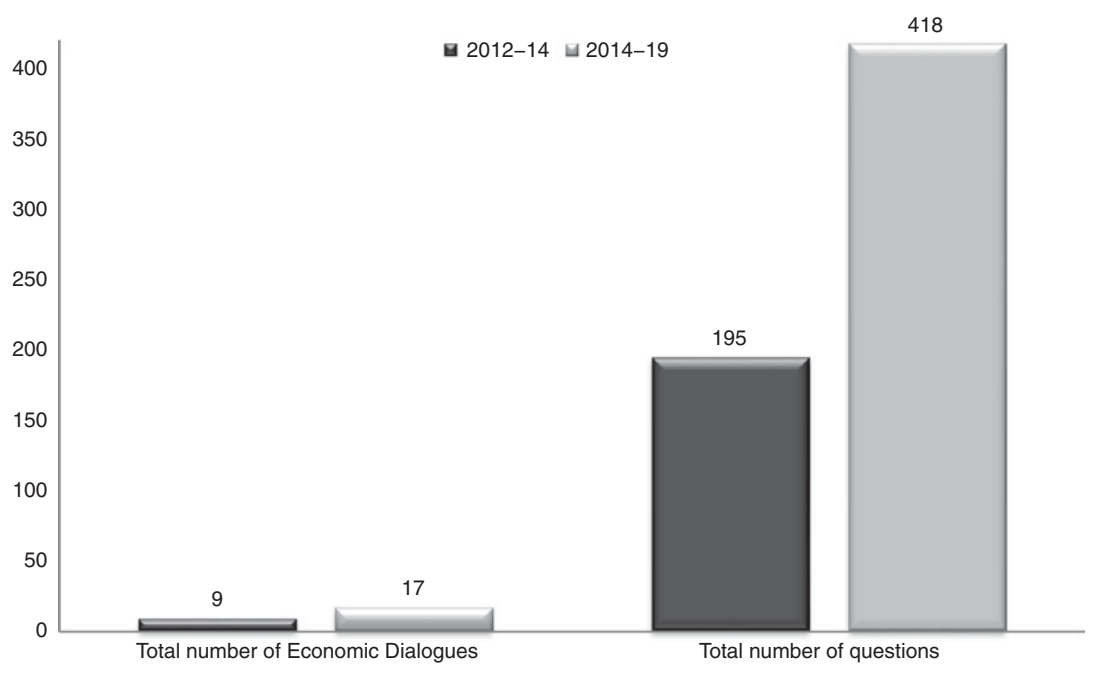

Figure 6.1 Number of Economic Dialogues with the ECOFIN Council Presidency and number of questions identified during each parliamentary term (2012-2014 and 2014-2019, respectively). 
In terms of the format of meetings, the ECON Committee introduced a change in January 2013 by establishing five-minute Q\&A slots for each MEP. This was clearly beneficial for the dynamic of the Economic Dialogues, in contrast to the 2012 meetings when many MEPs made long comments before asking a question (if a question was posed at all). Moreover, the practice of grouping several MEPs in one slot increased the likelihood for incomplete replies, for example, in the first Dialogue with Danish Minister Margrethe Vestager, the time limits did not allow her to address each question in turn; at the same time, when analysing the answers, it was sometimes hard to understand to whom she was replying exactly (a similar problem was found in the early Economic Dialogues with the Commission, see Chapter 5.3.2). The first sub-section discusses the profile of questioners and respondents in detail.

\subsubsection{Profile of Questioners and Respondents}

Who are the MEPs who ask questions during Economic Dialogues with the ECOFIN Council? In respect of nationality, the findings are consistent with the apportionment of EP seats to each Member State. Accordingly, the MEPs who take the floor most often come from the largest Member States: Germany, France, and Italy, and to a lesser extent the UK and Spain (Figure 6.2). There are, however, some discrepancies: most notably, MEPs from Greece and Portugal feature frequently in Economic Dialogues with the ECOFIN Council Presidency, despite having a lower number of MEPs. In contrast, MEPs from Poland and Romania rarely take the floor - although they have a much higher number of MEPs given the population of their countries. This discrepancy reflects the focus on Eurozone countries hit by the euro crisis; indeed, Greece and Portugal were highly affected (as were Ireland and Cyprus, but they have fewer MEPs by default). On a different note, there is no systematic correlation between the nationality of MEPs and the nationality of the minister holding the ECOFIN Council Presidency. The only exception is Italy, when four Italian MEPs asked questions of Minister Pier Carlo Padoan during Economic Dialogues with ECOFIN in 2014-2015.

Furthermore, when it comes to the party affiliation of MEPs asking questions of the ECOFIN Council Presidency, Figure 6.3 shows that the numbers are not entirely consistent with the proportion of seats held by each political group in the EP. For example, while the S\&D ranks second by size in both parliamentary terms (2009-2014 and 2014-2019), it is the leading group asking questions in the Economic Dialogues with ECOFIN. In fact, in the 2009-2014 parliamentary term, the EPP had almost 100 seats more 


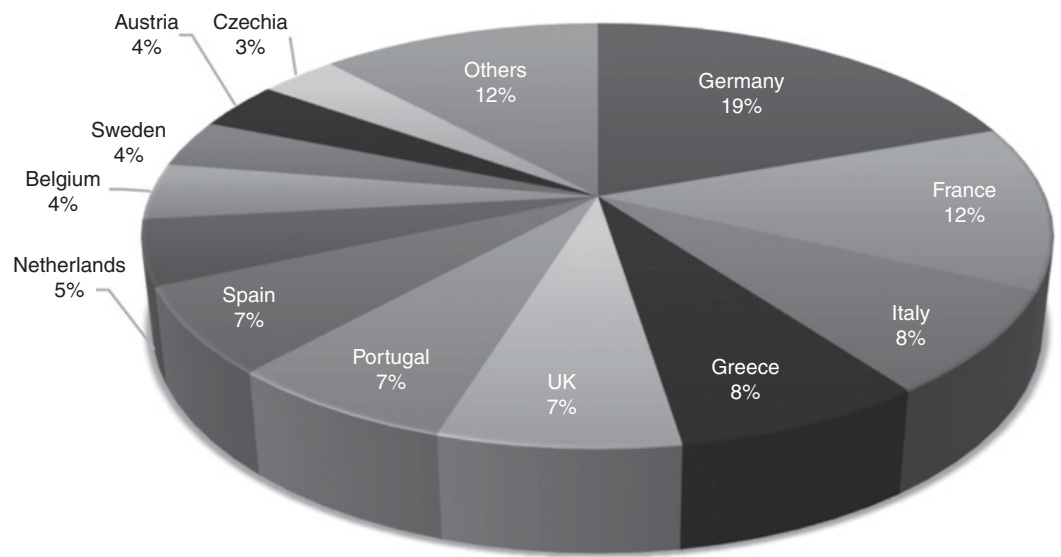

FIGURE 6.2 Nationality of MEPs taking the floor in Economic Dialogues with the ECOFIN Council Presidency (2012-2019). Total MEPs identified: 303

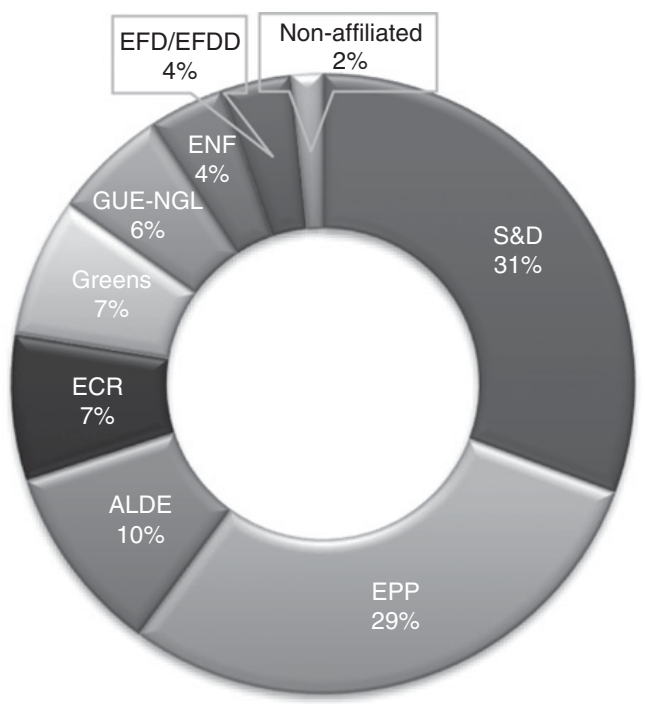

FIGURE 6.3 Political affiliation of MEPs taking the floor in Economic Dialogues with the ECOFIN Council Presidency (2012-2019). Total MEPs identified: 303

than the S\&D. The difference between the S\&D/EPP and other political groups is larger than their proportion of seats in the EP; in fact, in many meetings, after the mandatory round in which all political groups could take 
the floor, only MEPs from EPP and S\&D would continue to ask questions. This is a reflection of the topics covered in the meetings: since numerous questions revolve around legislative files currently under negotiation between the two legislators, there are more MEPs from EPP or S\&D who served as rapporteurs on these files. Otherwise, the order of the smaller political groups varies because their size changed in the two parliamentary terms: that is, ALDE and the Greens had more seats during 2009-2014, while the ECR and GUE-NGL increased their presence in the EP during 2014-2019.

Overall, the political affiliation and nationality of MEPs are important in terms of the variables expected to have a negative effect on legislative oversight: namely the multi-party system of the EP and its profile as a law-making parliament (Chapter 3.3.2). More specifically, the diversity of political and national interests represented in the EP is bound to lead to uncoordinated, diffuse questioning and few follow-ups (see also the dynamic with the Commission, Chapter 5.3). At the same time, the EP's long-term emphasis on law-making is reflected in the interactions with the Council by the relative dominance of MEPs who serve as rapporteurs on legislative files. Given their status as co-legislators with the Council, these MEPs tend to prioritise their legislative activity as opposed to the executive actions of the ECOFIN Council in the EMU.

Furthermore, in respect of the number of questions addressed to the different Council Presidencies, Figure 6.4 provides an overview in absolute numbers. On average, there were two Economic Dialogues per Presidency, organised at the beginning and at the end of the six-month period. The exceptions are Austria, Greece, Latvia, and Romania - which only participated in one Economic Dialogue at the ECON Committee. While the number of questions posed to each Presidency is relatively stable, the outliers are Lithuania, Cyprus, and Romania - which received, for instance, about half of the number of questions addressed to Luxembourg, Denmark, or Malta. There are two reasons why some Presidencies receive more questions: in some cases (such as Luxembourg and Malta), this has to do with domestic developments that attract media attention, for example, "tax haven' allegations connected to LuxLeaks and the Panama Papers. In other instances, Presidencies receive a high number of questions because they advance important legislative dossiers, as was the case of Denmark (2012), Ireland (2013), or Italy (2014).

Overall, the nationality and political affiliation of MEPs asking questions of the ECOFIN Council illustrates the lack of a particular country focus as well as the dominance of MEPs from the two largest political groups. 


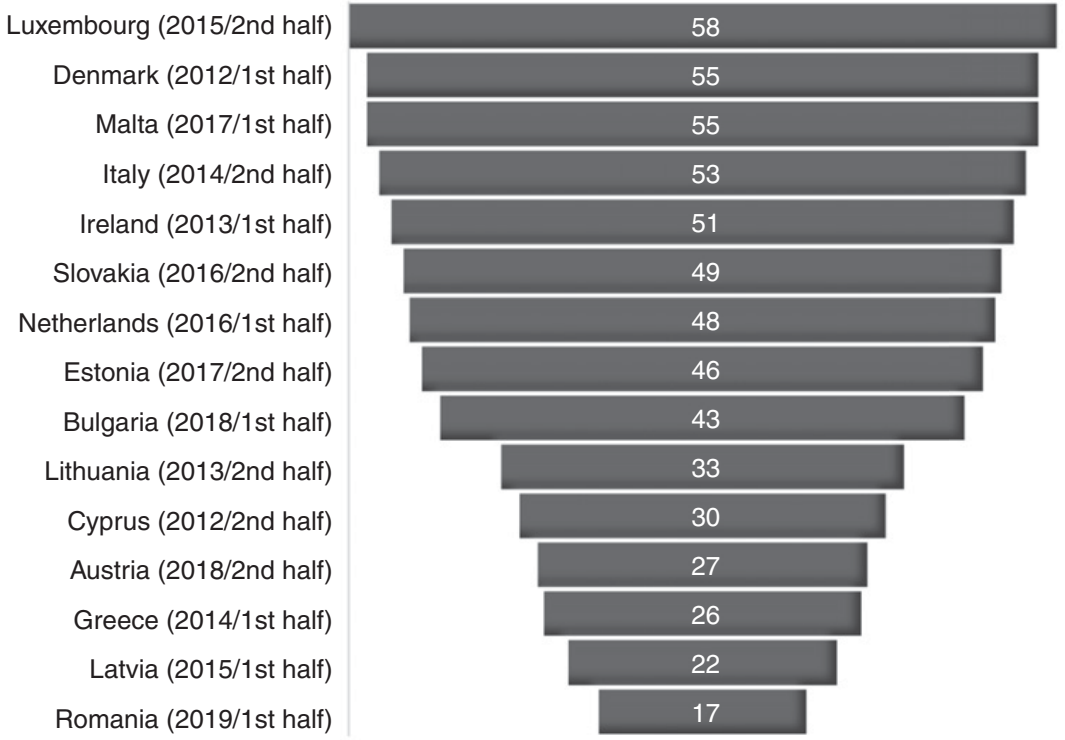

FIGURE 6.4 Number of questions addressed to each country holding the sixmonth ECOFIN Presidency. Total: 613

\subsubsection{Types of Questions Asked}

What kind of questions do MEPs ask in Economic Dialogues with the ECOFIN Council Presidency? Figure 6.5 shows that the majority of questions are requests for policy change (219), followed by requests for information (155). Often, MEPs would pose questions about ongoing legislative dossiers, taking a clear stance on their preferred amendments. Next, there are demands for justification of decisions (128) and questions about policy views (111). Questions requesting policy views encompass specific requests from MEPs on the Presidency's opinion on a variety of issues, such as the likelihood of finding compromises in the Council on given files, the assessment of the Presidency on Commission proposals or actions by the ECB, the Eurozone's prospects for growth, or the potential impact of envisaged reforms. Questions for policy views are open-ended, meaning that MEPs do not voice opinions on necessary reforms, which would imply requests for policy change.

Furthermore, Figure 6.5 reveals that the number of initial questions is higher than follow-up questions for all the five categories identified. This suggests that each MEP asks his/her own questions, with fewer instances of members pushing on a specific topic with multiple rounds of questions. 


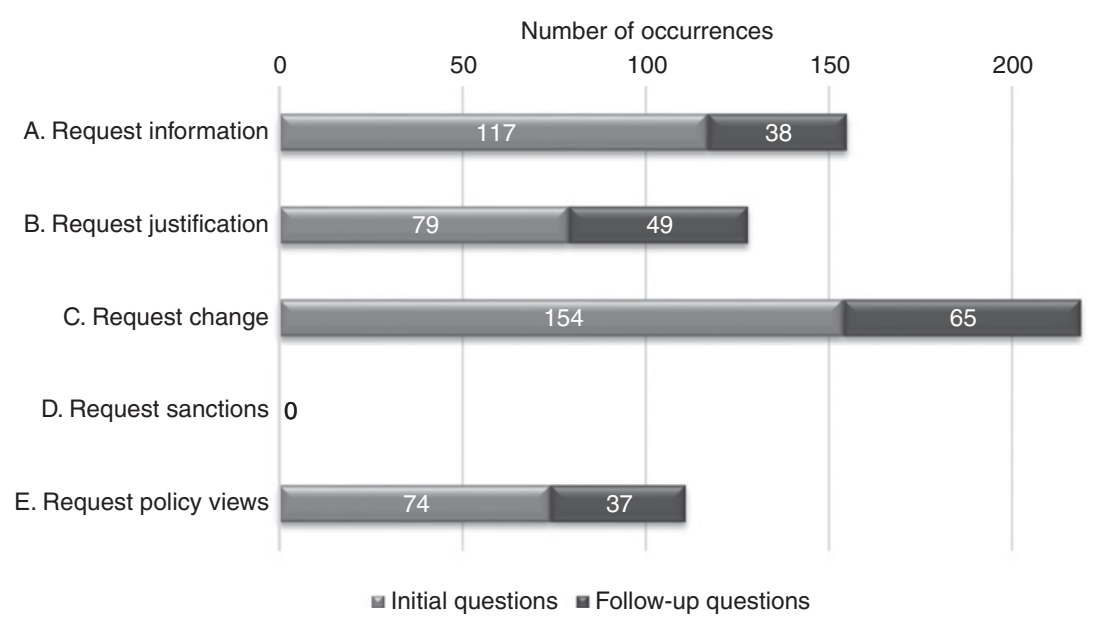

Figure 6.5 Types of questions identified in Economic Dialogues with the ECOFIN Council Presidency (2012-2019). Total questions: 613

Unlike in the Economic Dialogues with the Commission, no irrelevant questions were identified in the analysis (questions type F). The only 'dubious' performance of the ECON Committee was in the first meeting with the Estonian Presidency in July 2017, when several MEPs started their interventions with remarks about what a great country Estonia is, with beautiful landscapes and a successful e-governance infrastructure. Sven Giegold (Greens/EFA, Germany) even referred fondly to a holiday he had in the country in his youth (European Parliament 2017d). However, in the second Dialogue with Estonia, when it becomes clear that the minister has a tendency to evade questions (see below), the same Giegold pushes for replies to his very specific questions. Another instance of questionable conduct by MEPs is the Dialogue with the Bulgarian Finance Minister Vladislav Goranov on 12 July 2018. The meeting is scheduled early in the morning, and at the beginning, only two MEPs are present. Since the room is almost empty, the same two speakers take the floor twice on behalf of their colleagues. This raises questions about parliamentary interest in various ECOFIN Presidencies, based on their Eurozone membership or current controversies captured in the media.

Next, it is important to link the types of questions asked by MEPs with the policy issues raised during Economic Dialogues with the ECOFIN Council Presidency (Figure 6.6). By far, the topic at the forefront of most meetings concerns ongoing legislative files negotiated by the EP and the Council either 


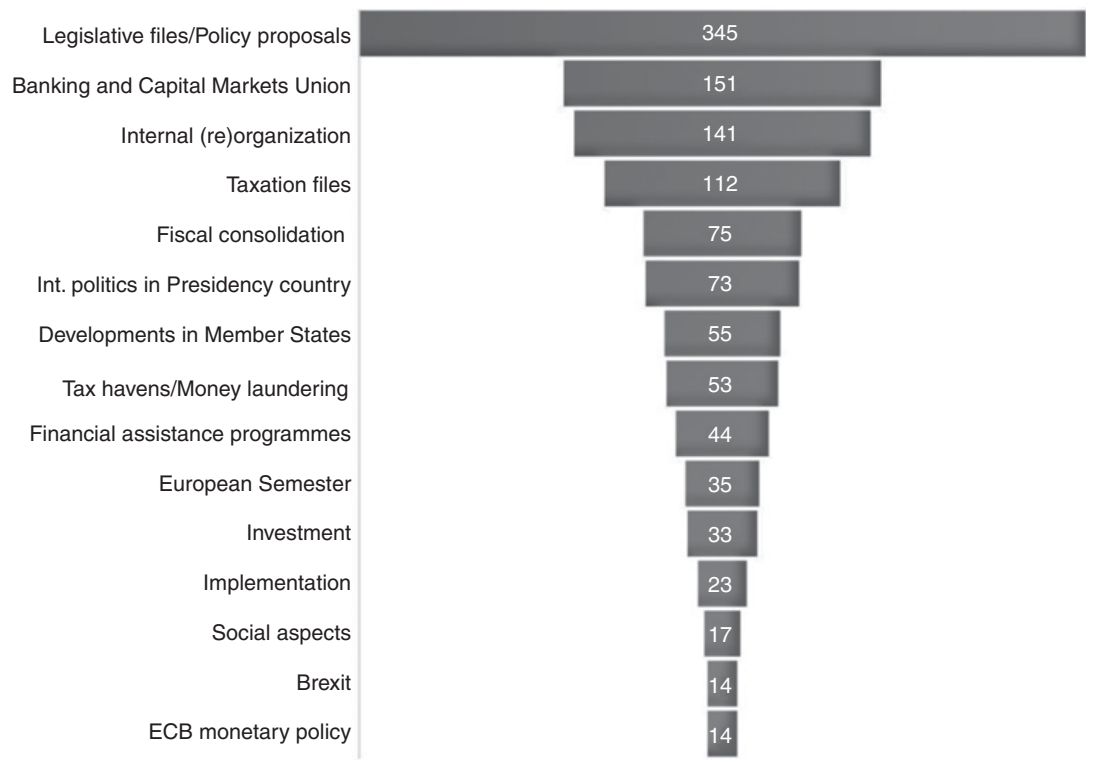

FIGURE 6.6 Range of issues raised by MEPs during Economic Dialogues with the ECOFIN Council Presidency (2012-2019). Most questions are assigned two codes.

Total issues: 1,186

through the ordinary or the special legislative procedure. This clearly reflects the profile of the EP as a law-making parliament (Chapters 1.2 and 3.3). In the data set analysed, questions on legislative dossiers feature in 346 out of the 613 questions identified. Most often, such questions refer to the Banking or the Capital Markets Union (151 times), taxation files (112 times), and less frequently issues concerning planned EMU reforms (46 times) envisaged in documents such as the Five Presidents' Report. In this context, MEPs often inquire about the status of negotiations (requests for information) or they express their own preference for outcomes on given legislative files (requests for policy change). In respect of the latter, the MEPs end the question by asking the ECOFIN Council Presidency what they think about their proposals or whether it is feasible. One Dialogue with more heated exchanges revolved around the negotiations on the SSM Regulation and the CRD IV in January 2013, during the Irish Presidency of the Council. In the meeting, several MEPs accused Minister Michael Noonan of withdrawing support for the compromises reached during the previous Cypriot Presidency. The minister defended his position by saying his team was conducting all the necessary meetings and trialogues, thus showing his country's commitment to solving 
the files. MEP Philippe Lamberts (Greens/EFA, Belgium) pointed out that the problem is not the lack of meetings but the diplomatic language of negotiators who obviously wanted to change things that had already been agreed (European Parliament 2013c). When it comes to questions on legislative dossiers, this meeting was among the few that clearly illustrated attempts by the EP to hold the Council Presidency accountable for its chairing of ECOFIN negotiations on legislative files.

By contrast, questions about the European Semester (including instruments such as the AGS, DBPs, or CSRs) are only present in 35 of the 613 questions identified. Such instruments are sometimes connected to questions about fiscal consolidation (reducing deficits and making structural reforms), identified in 75 questions; however, the discussion on fiscal consolidation can take place independently of the Semester, in connection with the overall EMU architecture and the need for policy reforms (26 times). This is very surprising, given that the main reason for establishing the Economic Dialogues was to discuss fiscal and macroeconomic developments linked to the Semester. In fact, the only meeting that clearly focused on the Semester is the Dialogue on 10 July 2012. In contrast to other meetings, Cypriot Finance Minister Vassos Shiarly did not focus his opening remarks on his country's Presidency priorities on ongoing legislative files. Instead, his speech centred on the recently adopted CSRs for that year, including descriptions of the 'comply -or -explain' principle applied to 10 out of 27 countries. The introduction sets a different tone for the meeting, which ended up debating concrete differences between the Commission proposals and the final version of CSRs adopted in the Council (European Parliament 2012b). Another novelty is that the minister came accompanied by his country's EU ambassador, who answered the more specific questions on the Semester. A nice example of a request for information about the decision-making process behind CSRs can be found below:

Olle Schmidt (ALDE, Sweden): I wonder how the discussion, the debate is going on, because you have a recommendation, and then you do some changing in them and then you do some [more] last-minute changes. How is this actually happening and what is the reasoning behind this? Because that would be interesting to hear. Is it an open debate or is it solved beforehand? (European Parliament 2012b)

From a legal perspective, the Dialogue with Cyprus on 10 July 2012 remained the only meeting where the topics of questions followed the rules set out in the Six-Pack. Otherwise, MEPs continued to use meetings with the ECOFIN Council Presidency in the same way they did before the Six-Pack (and before 
the crisis for that matter), namely to inquire about the status of negotiations on legislative files. From this perspective, it is clear that the Economic Dialogues with the ECOFIN Council Presidency are a missed opportunity for the EP to oversee the activities of the ECOFIN Council as an executive rather than as a legislative body.

Moreover, the interactions between MEPs and the Council Presidency can be described as peaceful if not friendly; it is rare that MEPs confront a finance minister about anything. One example refers to domestic political issues in the Presidency country (present in seventy-three total questions) when MEPs inquire about tax haven allegations made against Luxembourg in 2015, the Netherlands in 2016, and Malta in 2017 (identified fifty-three times). Based on revelations associated with LuxLeaks and the Panama Papers, several MEPs criticised the tax regimes of these countries and demanded justification of conduct and changes in national tax policy. For instance, during both Economic Dialogues with the Maltese Presidency in the first half of 2017, Finance Minister Edward Scicluna was repeatedly asked about the tax system of his country, so much so that ECON Committee Chair Roberto Gualtieri reminded MEPs that the minister was present in his capacity as ECOFIN President - not as finance minister of Malta - meaning that questions should be raised accordingly (European Parliament 2017b). The intervention of the Chair is problematic, keeping in mind that at the start of the meeting on 25 January 2017 , he mentioned that he was friends with the minister (who was a former MEP).

Overall, the Economic Dialogues with Malta are the most confrontational in the data set, as MEPs also criticise the Council's lack of cooperation with the EP's special investigative committee on the Panama Papers (the PANA Committee). One issue mentioned repeatedly was transparency, especially the PANA Committee's access to tax ruling documents available in the Council. And since the ECOFIN Council Presidency was at the time held by a country accused of being a 'tax haven', several MEPs attacked the minister for keeping important documents secret and thus limiting the EP's inquiry into the topic. Indeed, the meetings with the Maltese minister are one of the few instances of Economic Dialogues with ECOFIN when the EP came across as a strong accountability forum (European Parliament 2017b).

On a different note, MEPs also ask about financial assistance programmes (forty-four times) in different countries and public investment, especially Juncker's Investment Plan for Europe (thirty-three times). Far less discussed are implementation issues (mentioned on twenty-three occasions) and social problems such as unemployment, poverty, and the impact of austerity more generally (identified seventeen times). In contrast to meetings with the 
Commission, MEPs rarely raise social issues with the ECOFIN Council Presidency - although the adoption of CSRs is ultimately done by the Council after the preparatory bodies (the EPC and the EFC) discuss Commission proposals.

Having reviewed the types of questions addressed in the Economic Dialogues with the ECOFIN Council Presidency, the focus now moves to the range of answers received by MEPs in response.

\subsubsection{Types of Answers Provided}

How does the ECOFIN Council Presidency answer questions from MEPs asked during the Economic Dialogues? The data set shows that the majority of questions (313) are answered explicitly, while the rest are answered partially (210) or constitute non-replies (90). Figure 6.7 offers an overview of the types of answers identified, capturing the variation in the willingness of finance ministers to engage with different types of questions. While answers providing information and answers to requests for policy change have similar ratios in the three categories (explicit, intermediate, and non-replies), there is a difference when it comes to requests for justification of conduct and policy views. On average, ministers are more likely to engage with these questions fully, providing an explicit reply.

Intermediate replies also occur frequently for all categories of questions. One example comes from the Dialogue on 21 January 2015 with the Latvian Finance

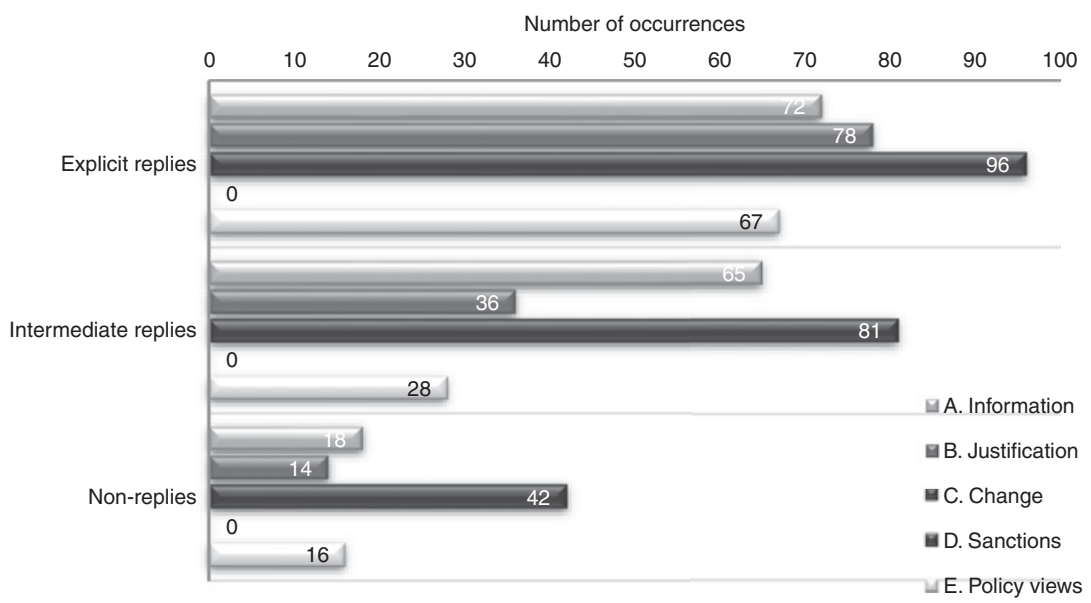

FIGURE 6.7 Types of answers received by MEPs in Economic Dialogues with the ECOFIN Council Presidency (2012-2019). Total replies identified: 613 
Minister Jānis Reirs, who answered most questions by drawing comparisons to domestic developments in his country. In fact, ten out of his total twenty-two replies were intermediate, as the minister did not seem too familiar with several legislative files currently negotiated at the EU level. Although his lack of knowledge could be justified by his recent appointment (less than three months in office at the time of the Dialogue), the minister had a clear tendency to avoid questions rather than engage with them (e.g. he provided six non-replies). A different yet equally unresponsive style can be found in the Dialogue with the Estonian Finance Minister Toomas Tõniste on 11 July 2017. The minister tended to give very brief answers, not going into details for any question. Overall, he provided ten intermediate replies, ten non-replies, and seven explicit replies. However, his short and dry answers seem to be more of a personal feature rather than a lack of interest in engaging with the EP.

On a different note, there were instances when a finance minister avoided or refused to provide policy views on a topic because of the required neutrality of holding the ECOFIN Presidency. In this respect, a relevant exchange occurred during the meeting on 22 January 2014 with the Greek finance minister:

Hans-Peter Martin (Non-affiliated, Austria): What is your position on the forthcoming structural reforms of the banks? On the Liikanen report basis and the perspective of the postponed Commission proposal.

Yiannis Stournaras (ECOFin Presidency, Greece): Actually, we are waiting for this report. If I'm right, ... the Commission will make a proposal towards the end of the month and then we'll take it to ECOFIN. Hans-Peter Martin (Non-affiliated, Austria): Well, actually, my question wasn't about the procedure, but about your position on the substance.

Yiannis Stournaras (ECOFin Presidency, Greece): I haven't seen the report yet, so I'm just waiting for the Commission proposal.

Hans-Peter Martin (Non-affiliated, Austria): But my question is really very specific. What's your position?

Yiannis Stournaras (ECOfin Presidency, Greece): Well, as an economist and an ex-banker, I have many ideas about the problem. But now I am the President of ECOFIN, so I have to be very careful. I have to see the report of the Commission first before I make [an opinion]. ... So be patient. (European Parliament 2014)

Apart from non-replies related to the perceived neutrality of the ECOFIN Presidency, there were cases when ministers simply refused to engage with questions. The most blatant example of this dynamic was found in the 
Dialogue with the Romanian Finance Minister Eugen Teodorovici on 24 January 2019. First, the minister gave the longest introductory remarks to date, where he effectively listed all legislative dossiers currently under negotiations between ECOFIN and the EP. When the first two speakers pushed him to outline three to four concrete priorities of the Presidency where the minister believes progress was possible, he dodged the question twice before finally answering. Several MEPs complained about the lack of preciseness in the minister's answers - most vocally Siegfried Muresan (EPP), a member of an opposition party in Romania. What is surprising in this case is that the nonreplies are in response to easy questions about the government's priorities for the Presidency or the national point of view (as a non-Eurozone country) on the creation of a Eurozone budget. It is hard to understand why the minister avoided giving a clear answer to this type of question. In fact, the minister has the worst record on responsiveness among ECOFIN Presidents, having answered explicitly only five of the seventeen total questions addressed to him.

Next, when examining the range of answers more closely (Figure 6.8), we can observe that finance ministers representing the ECOFIN Council Presidency tend to reply to the majority of questions through justification. In other words,

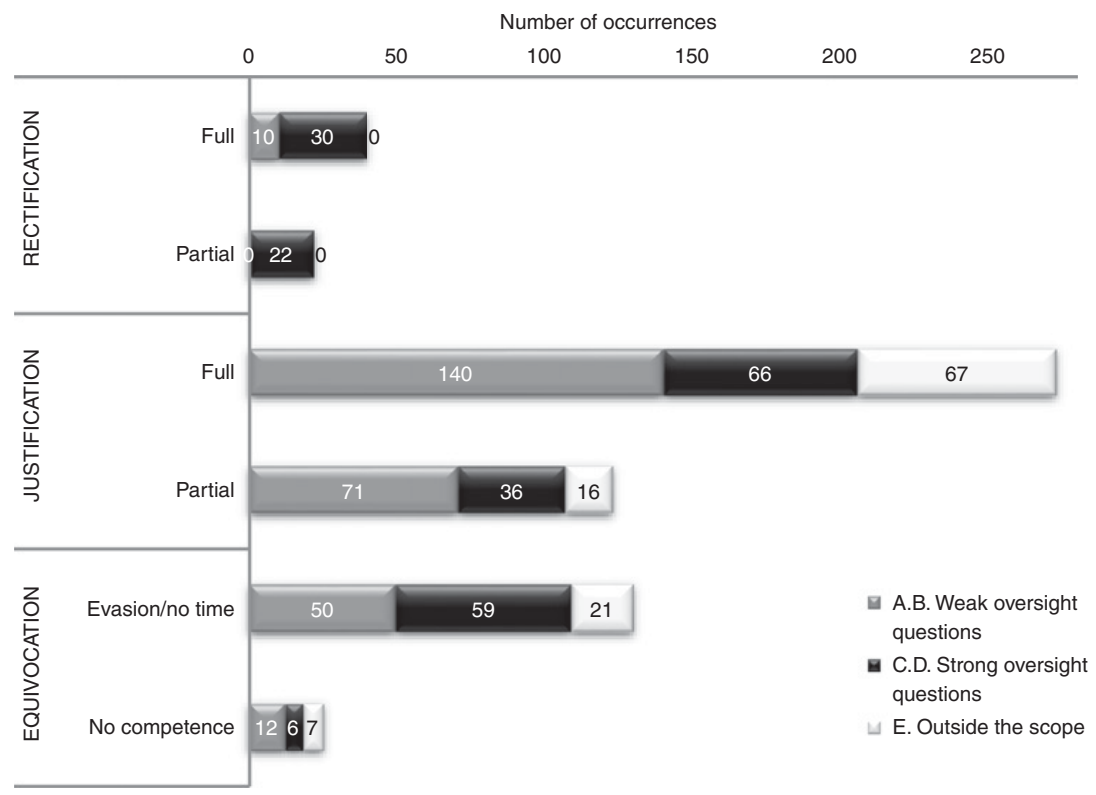

FIGURE 6.8 Degree of responsiveness by ECOFIN ministers holding the Presidency in Economic Dialogues (2012-2019) 
when challenged through parliamentary questions, ECOFIN ministers provide information about their decisions and decision-making processes, rationales for adopting them, or defend their conduct. The high number of policy views is also subsumed under justification, although technically they are outside the scope of legislative oversight (because requesting policy views does not engage with the past activity of an actor, so it is beyond the purpose of accountability).

One illustrative example of justification comes from the Dialogue with Dutch Finance Minister Jeroen Dijsselbloem on 14 June 2016, when Green MEP Philippe Lamberts (Belgium) lamented the lack of progress in the negotiations on EDIS, saying that he had hoped for more from the Dutch Presidency - as opposed to sending the Commission back to the drawing board' and delaying the completion of the banking union until 2024. The minister defended the conduct of the Presidency with an ironic answer, matching the tone of the MEP:

Jeroen Dijsselbloem (ECOFin Presidency, Netherlands): You expected so much more from the Dutch Presidency. We just aim to deliver. You know, this is what we do. We aim to please you. But we still have a couple of days left. Maybe we can improve the final grade that you will give us. So, you say that we're sending the Commission back to the drawing board. I don't think that is true. We are talking about the whole roadmap and how to take the next steps in the coming years. Also, technical work is already being done at Council level on the EDIS proposal itself. So, the Council has taken up on that proposal. Will it be changed in these negotiations? Of course, it always does. But that doesn't mean by sending the Commission back to the drawing board. You're worried about 2024? I'm not. This was already agreed also between us and the Parliament that the resolution fund should be fully completed and set up by 2024. (European Parliament 2016d)

By contrast, Figure 6.8 shows that instances of rectification happen rarely, albeit in response to demands for policy change (on fifty-two occasions). For instance, in the first Dialogue with the Bulgarian finance minister, MEP Paul Tang (S\&D, Netherlands) pushed for the Council to take into account the EP position on the Common Consolidated Corporate Tax Base (CCCTB) file. In fact, a lot of questions since 2016 onwards concern taxation files. The minister replied clearly:

Vladislav Goranov (ECOFin Presidency, Bulgaria): Of course, we will take it into account. We know what the role of the European Parliament here is. I'm a supporter of CCCTB. We are looking forward to your position and we will take it into account. (European Parliament 2018b) 
This means that the ECOFIN Council Presidency is in principle open to listening to the voice of MEPs. The more concerning trend is the relatively high number of equivocations, which occur not only by dodging questions or running out of time for responses but also by providing generic replies that acknowledge the topic of questions but do not respond to the query in any meaningful way (present in forty answers overall). An illustration of the generic replies can be found in this exchange from the Dialogue with the Austrian Presidency:

Othmar Karas (EPP, Austria): And what will you do to make sure that the CSRs of the European Semester are more quickly and completely implemented within Member States?

Hartwig Löger (ECOFin Presidency, Austria): Structural reforms within the Semester? Well, I did say in my introductory remarks that we would be doing everything possible to try and find substantive points which would ensure this is possible. (European Parliament 2018a)

While the minister acknowledges the topic of the question, he does not refer to the implementation of CSRs specifically or give any indication about what the Council will be doing on the topic.

\subsubsection{Summary}

Overall, the Economic Dialogues with the ECOFIN Council show a clear focus on legislative negotiations under the ordinary and special legislative procedures. The ECOFIN Presidency attended ECON Committee meetings prior to the crisis, so in practice little has changed in the interactions between the two institutions since the introduction of the Economic Dialogues in 2012. The emphasis on legislative negotiations corresponds to the classic relationship between the EP and the Council as co-legislators: if anything, MEPs use the Economic Dialogues with ECOFIN in order to exercise influence on future decisions to be made in the EMU. By contrast, there is little ex post oversight of executive actions taken by the ECOFIN Council. Although there were a few instances when MEPs asked about the European Semester in particular, the Economic Dialogues with the ECOFIN Presidency are generally divorced from the legal framework of the Six-Pack on transparency and accountability. When there are controversies in the Member States - for example, the 'tax haven' scandals - MEPs take advantage of the presence of a finance minister in the EP to ask questions about domestic issues. Nevertheless, the practice is rarely related to economic and fiscal policy coordination or the parliamentary scrutiny of the Semester. 
For their part, ECOFIN Presidencies are different, depending on the expertise of the incumbent on EU matters: the more a finance minister knows about the specific EMU issues discussed, the more comprehensive his or her answers. This opens an important question about the appropriateness of holding the current Presidency accountable for the activities of the ECOFIN Council as a whole. Formally, the Council Presidency is supposed to represent the entire institution - not only the reunion of ministers but also the preparatory bodies (senior committees and working parties). The extent to which the incumbent ECOFIN President has knowledge of discussions and negotiations held at various levels depends on the country holding the Presidency and the person involved. In the period under analysis, most finance ministers present in the Economic Dialogues appeared to make an effort to engage with questions from MEPs - with the exception of the Romanian Presidency. At the same time, the number of intermediary and non-replies is not negligible, as finance ministers were sometimes found to dodge questions or provide generic answers on the topic under debate. On average, their performance is worse than that of the Eurogroup President, as shown in the next section.

\subsection{THE ECONOMIC DIALOGUES WITH THE EUROGROUP PRESIDENT}

The first Economic Dialogue with the Eurogroup President took place in March 2013, in connection with the upcoming entry into force of the TwoPack. Since then, there have typically been two Economic Dialogues per year, in March and September, in line with the Eurogroup practice to adopt a work programme every six months. Each programme broadly defines the main areas on which the Eurogroup plans to focus its efforts. An exception to the practice of biannual meetings occurred in 2013, when four Economic Dialogues took place in the context of Juncker's ending mandate as Eurogroup President (in January) and a special meeting on the ESM adjustment programme for Cyprus (in May). Another exception is 2019, when there was no meeting in March due to the upcoming organisation of EP elections. From the four institutions analysed in this book, the Eurogroup clearly has the fewest direct interactions with the EP.

In total, there have been 14 Economic Dialogues in the period under investigation (Figure 6.9), during which 474 questions were identified. Typically, the Economic Dialogues with the Eurogroup President include on average 30 questions per meeting. 


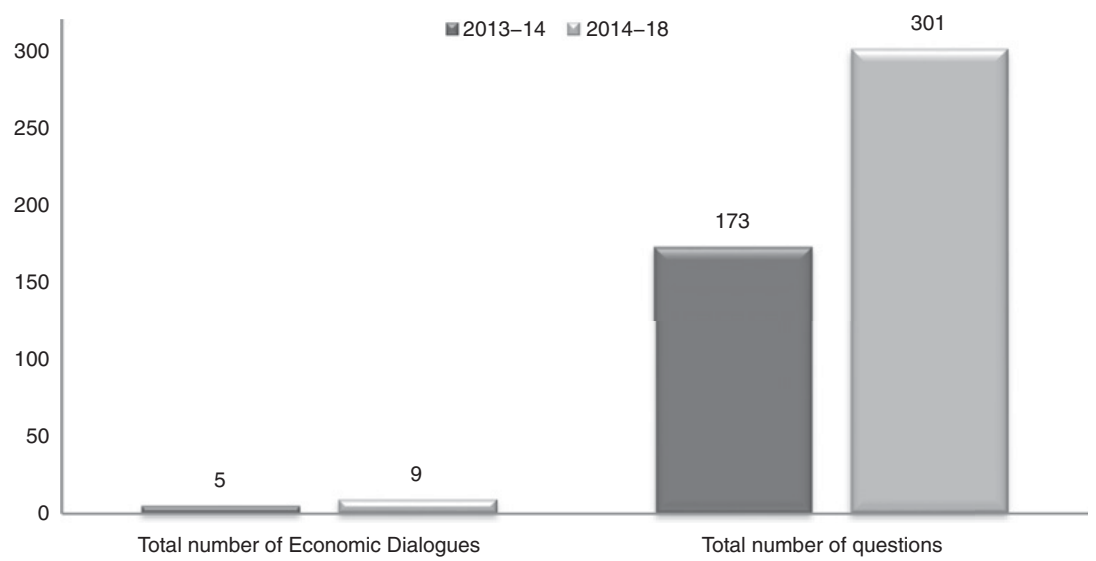

FIGURE 6.9 Number of Economic Dialogues and questions addressed to the Eurogroup President during different parliamentary terms (2013-2014 and 20142018)

As a general observation, the Economic Dialogues with the Eurogroup President tend to last longer than similar meetings with the ECOFIN Council Presidency. Moreover, if smaller political groups sometimes fail to ask questions in the Economic Dialogues with ECOFIN, this rarely happens in meetings with the Eurogroup President. Indeed, the stakes are much higher in Economic Dialogues with the Eurogroup, which also serves as the ESM Board of Governors and thus directly takes decisions on financial assistance programmes. As such, it is not surprising that the ECON Committee room is full whenever the Eurogroup President is attending - in contrast to ECOFIN meetings. The next section discusses the profile of MEPs asking questions and that of the respondents on behalf of the Eurogroup.

\subsubsection{Profile of Questioners and Respondents}

The profile of MEPs asking questions in the Economic Dialogues with the Eurogroup President follows the patterns of interactions with other institutions (Chapters 4 and 5). First, in respect of nationality (Figure 6.10), there is a partial correlation with the national apportionment of seats in the EP and a partial overlap with countries that were subject to financial assistance programmes from the ESM. Consequently, while Germans still take the floor most often (on fortyfive occasions), they are followed by MEPs from Greece (twenty-six times). Portuguese MEPs also rank in the top ten, as do those from the Netherlands and Belgium - a feature likely related to the nationality of the Eurogroup 


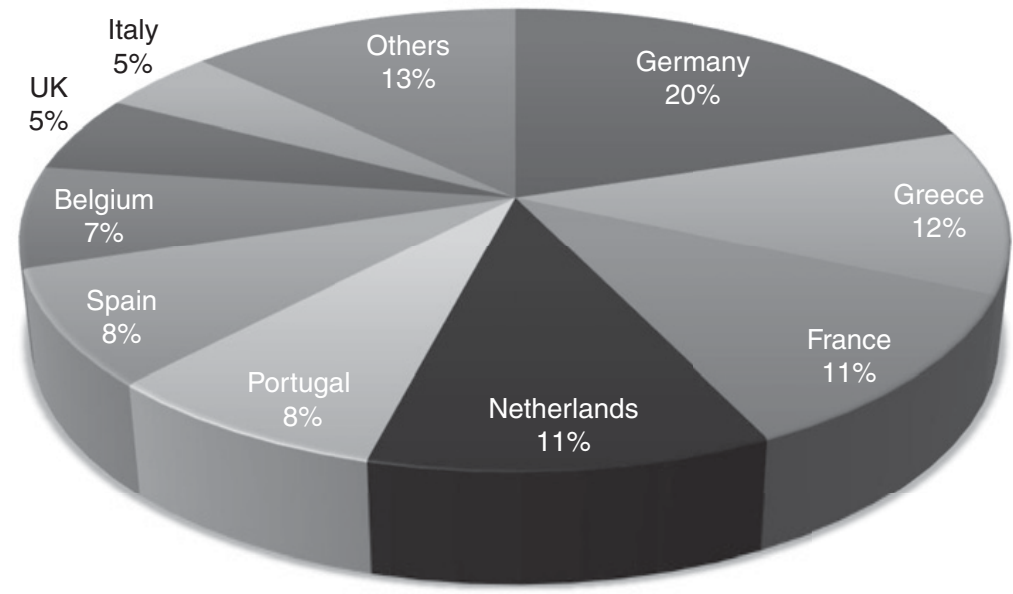

FIGURE 6.10 Nationality of MEPs taking the floor in Economic Dialogues with the Eurogroup President (2013-2018). Total MEPs identified: 224

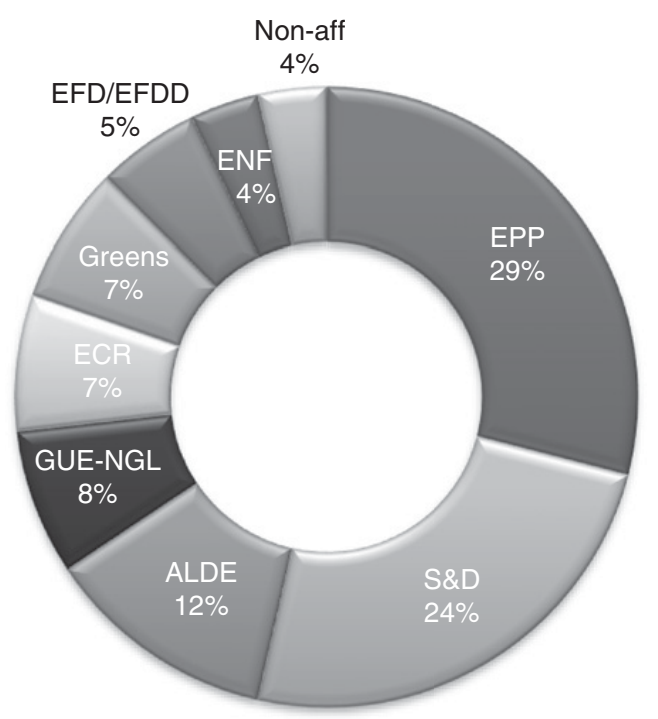

FIGURE 6.11 Party affiliation of MEPs taking the floor in Economic Dialogues with the Eurogroup President (2013-2018). Total MEPs identified: 224

President for most of the period under analysis (Dutch Finance Minister Jeroen Dijsselbloem, 2013-2018). The surprise here comes from the lack of questions from Italian MEPs (only ten during the period under focus), who tend to be more 
active in meetings with the Chair of the Supervisory Board of the ECB (Chapter 4) and the Commission (Chapter 5). By contrast, other absences are to be expected, for example, MEPs coming from large non-euro area countries (the UK, Poland, and Romania) are less likely to ask questions of the Eurogroup President.

Next, when it comes to party affiliation (Figure 6.11), the distribution of MEPs taking the floor in every meeting reflects the political allocation of seats in the EP: during the period under investigation, the EPP is first (identified on sixty-five occasions), followed by the S\&D (with fifty-five interventions). Relative to their representation in the EP, MEPs from ALDE ask questions of the Eurogroup President more frequently (on twenty-seven occasions), while the ECR typically intervenes once per session, as prescribed by EP rules. As with other Economic Dialogues and EP hearings, the coordinators of political groups take the floor in almost every meeting: for example, Jean-Paul Gauzès (EPP, France) and Elisa Ferreira (S\&D, Portugal) for the 2009-2014 parliamentary term and Burkhard Balz (EPP, Germany) and Pervenche Bères (S\&D, France) during 2014-2019.

Furthermore, the Economic Dialogues with the Eurogroup had different interlocutors over time, in line with the changing Presidents of the intergovernmental body (Figure 6.12). Accordingly, MEPs met with Jean-Claude Juncker (in 2013), Jeroen Dijsselbloem (during 2013-2017), and Mário Centeno (in 2018). Figure 6.12 shows that Dijsselbloem answered most questions - which is not surprising since he occupied the office for the longest time during the period under investigation. By contrast, Juncker attended one meeting, while Centeno was present in two. For the Dialogue in November 2015, the ESM Managing Director Klaus Regling accompanied

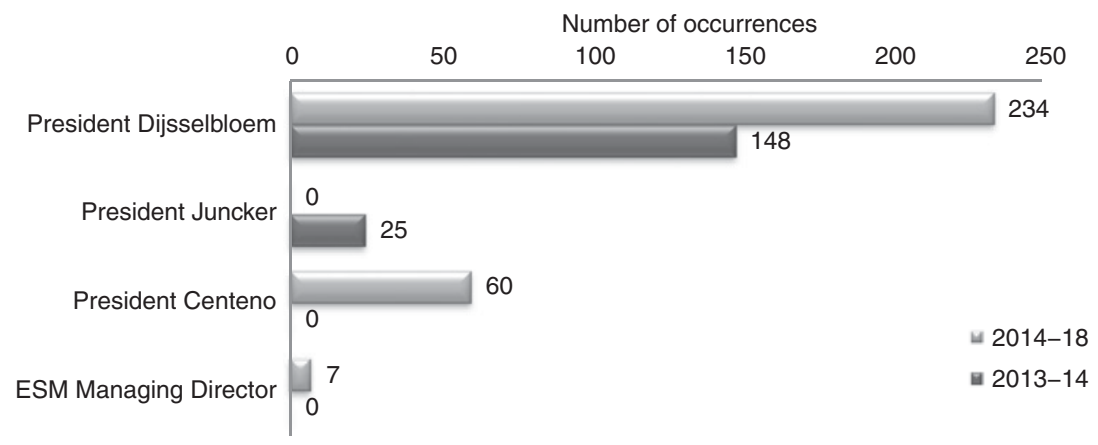

FIGURE 6.12 Number of questions addressed to different interlocutors during Economic Dialogues with the Eurogroup President (2013-2018) 
Dijsselbloem to discuss the latest adjustment programme for Greece. In fact, this meeting is split into two: the first part is considered 'an ad hoc exchange of views on Greece' (following the eventful summer of 2015), while the second half is the 'regular Economic Dialogue' of that autumn.

Having established the profile of questioners and respondents, the following pages provide an overview of the substance of interactions between MEPs and the Eurogroup President in the Economic Dialogues.

\subsubsection{Types of Questions Asked}

What type of questions do MEPs pose to the Eurogroup President? Figure 6.13 shows that the majority of questions are demands for changes of decisions or conduct (166 times), followed by demands for justification (145 times). Requests for information and policy views are almost identical (82 and 81, respectively). While most questions are related to the activity of the Eurogroup as an EU body, there was one instance where the personal conduct of the Eurogroup President was contested due to remarks he made in the media. At the meeting on 21 March 2017, several Spanish MEPs confronted Jeroen Dijsselbloem for claiming in reference to Southern European countries that 'one cannot spend all the money in drinks and women and then ask for help [from] the Eurozone' (European Parliament 2017c). The minister defended

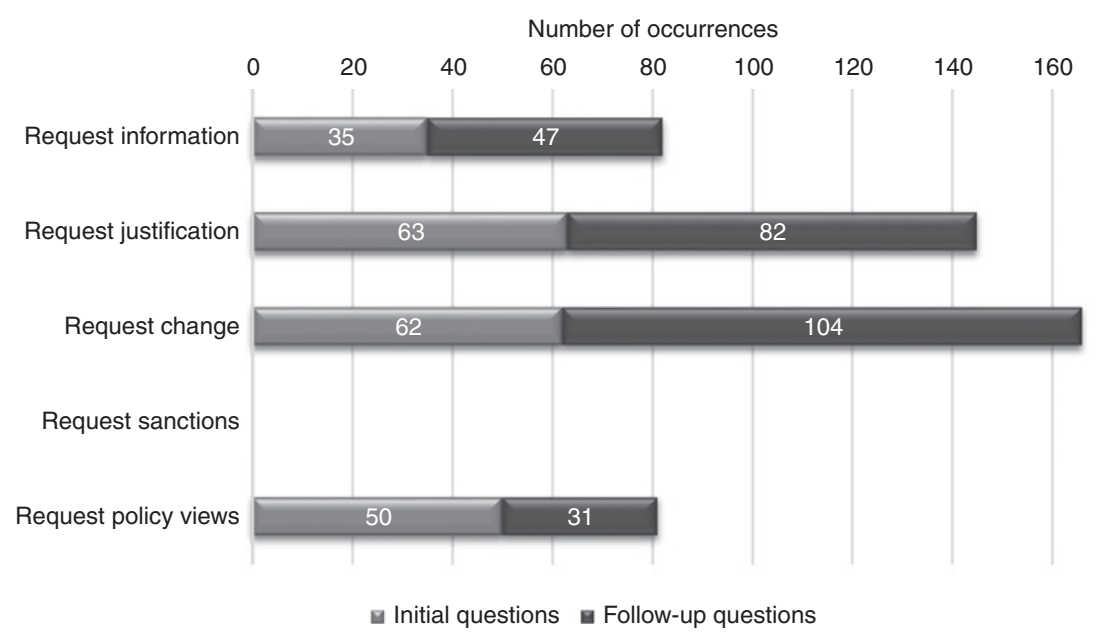

FIgURE 6.13 Types of questions identified in Economic Dialogues with the Eurogroup President (2013-2018). Total questions: 474 
his statements over and over again, saying he was talking about collective efforts to maintain solidarity in the Eurozone - and that his remarks could also apply to the Netherlands. After several back-and-forth exchanges on the topic, MEP Gabriel Mato (EPP, Spain) concluded that the minister missed a third opportunity to apologise' and consequently lost his authority as an impartial Eurogroup President. Unrelated to this controversy, Dijsselbloem was about to lose his mandate as Dutch finance minister following national elections which resulted in his replacement as Eurogroup President by the end of the year.

Furthermore, as a general trend, the Economic Dialogues with the Eurogroup President are characterised by a high number of follow-up questions, with MEPs continuing to push for answers on specific topics. An example is the special Economic Dialogue that took place on 7 May 2013 on the ESM adjustment programme for Cyprus. The meeting started strongly with ECON Committee Chair Sharon Bowles asking twelve questions that requested information about the negotiation process or justification of conduct about the mistakes made. Some iconic questions are extracted below:

Sharon Bowles (Chair, Econ Committee): ... why was the situation allowed to worsen until such time as the two largest Cypriot banks collapsed? What lessons have been learned from the previous experiences with Iceland, Ireland, Spain, and Greece that might have been deployed to good effect in Cyprus? (...) How did the Euro Summit meeting on the night of the 15th and 16 th of March reach its conclusions? (...) How was the meeting prepared and by whom? And actually, we're still a little bit curious about who was in the room and how many in particular from the IMF and whether there were any sub rooms. (...) Did the Cyprus authorities provide or withhold all relevant information at all stages of the crisis? (...) And how can we be certain or not that the best value was achieved in the interest of the Cypriot people? (...) but more importantly, we'd quite like to know who opposed the levy on small depositors. And were other wealth tax options investigated or why was a wealth tax targeted just on deposits? (...) How do the capital controls in Cyprus that were applied and some of which still apply conform to EU rules? And can we establish that there has been equality of citizens and Member States in the various bailouts? And is this within both the spirit and the letter of the Treaties and legislation? (European Parliament 2013d)

This is a remarkable example of accountability at work, as we see the EP demanding very concrete information and justification of conduct about the 
decision-making process, the legality of the decisions, and the general fairness of the outcome for Cyprus. In response, Dijsselbloem engages with eleven of these questions in his introductory remarks; the only issue he leaves aside concerns the equality of Cypriot citizens to other EU citizens whose countries were under ESM programmes. The meeting continues with numerous questions on Cyprus, the mistakes of the Eurogroup on the matter, and the need to reform the ESM by bringing it under the democratic control of the EP. Throughout the Dialogue, Dijsselbloem holds his ground and defends the position of the Eurogroup:

Jeroen Dijsselbloem (Eurogroup President, Netherlands): In the Cypriot case, there was a big burden to be carried and there were only a few options. Who is going to carry the burden? We couldn't pass the burden onto the Cypriot government because that would simply not have been sustainable and there would have been no future for Cyprus for a very, very long time. We couldn't pass it on, the whole burden, to the ESM. That would still be a loan to the government and we would have the same problem. We considered [it] because some thought it preferable to put the burden on all the deposits, as you know. That was the first solution within Cyprus. The fallout of that was that people hesitated or were worried about the effects that would have on the deposit guarantee system, which was a completely different thing than the levy. But this was the concern that arose. So finally, the burden was put on those investors and the uninsured depositors of two banks where the main risks were concentrated. Is that a fair way to deal with this crisis in the banks of Cyprus? I think so. And I stand to defend that. (European Parliament 2013d)

Next, which issues do MEPs raise with the Eurogroup President? Figure 6.14 shows that the most discussed topics by far refer to ESM financial assistance programmes ( 187 out of the 474 questions), which often goes hand in hand with developments in Member States other than the country holding the Eurogroup Presidency (167). In fact, out of the 184 questions that address financial assistance programmes, 97 are about Greece (many from 2015) and 58 about Cyprus (the majority from 2013). This finding corresponds to the special Economic Dialogues held on the Cyprus adjustment programme in May 2013 and the ad hoc exchange of views on Greece organised in November 2016. Legislative files also often refer to the Banking and Capital Markets Union ( 75 occurrences), especially the adoption of the SSM, the SRM, and the deadlock of negotiations over EDIS.

Another popular topic refers to planned reforms to the EMU architecture (166 times), especially the Five Presidents' Report and the importance of 


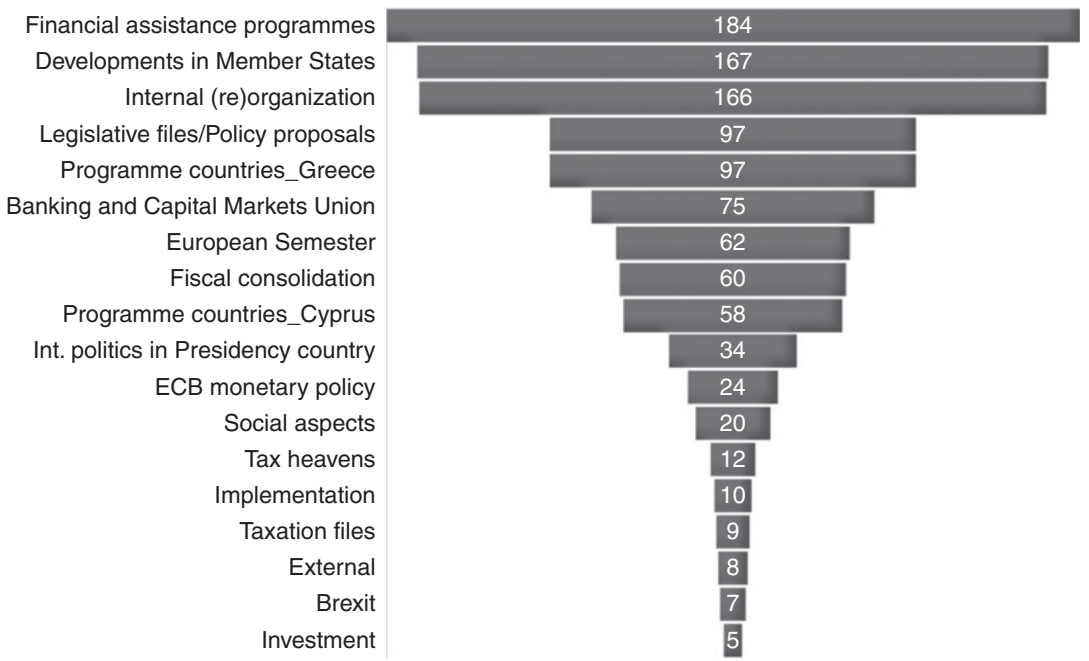

FIgURE 6.14 Types of issues raised by MEPs in Economic Dialogues with the Eurogroup President (2013-2018). Most questions have two codes, except those that address ESM programme countries, Greece and Cyprus (which have three codes).

Total codes assigned: 1,095

integrating the ESM into the Treaties. In fact, MEPs have often voiced their criticism of the intergovernmental nature of the ESM and the need to transform it into a European Monetary Fund accountable to the EP. From this perspective, the code 'internal organisation/EMU architecture' often comes together with 'legislative files/policy proposals' or 'financial assistance programmes'. MEPs have repeatedly demanded increased accountability of the ESM, although the Eurogroup has constantly defended the matter in relation to national parliaments. The dynamic is evident in this exchange from the Dialogue on 20 February 2014:

Jeroen Dijsselbloem (Eurogroup President, Netherlands): The ESM is as you know basically intergovernmental and therefore the ministers ... will go to the national parliaments and be accountable in the national parliaments. There is also if I understand correctly my predecessor Mr Juncker sent a letter to Parliament saying that the EP would be informed on a regular basis on the works of the ESM. And we are always ready and able to do so.... That's why I am here. You see, sometimes you can make things complicated. The easy thing is I am here now. You can ask me anything you want on the ESM. 
Bas Eickhout (Greens/EFA, Netherlands): ... you know very well that for example the Dutch Parliament does not have a veto on any payments and whereas the German Parliament has because of the voting rules. So there is a democratic gap in the ESM and - by promised democratic scrutiny of the Parliaments - that is more than just you that you are here [every] couple of months' time. So how to improve that democratic scrutiny; that's more than just have a nice talk.

Jeroen Dijsselbloem (Eurogroup President, Netherlands): . . . if you think the Dutch Parliament will let for example programs and disbursements from programs to countries from the ESM pass, likely you are mistaken. There is no subject that is debated that much and that often in the Dutch Parliament as the Eurozone agenda including all the programs and all the money that comes from the ESM is heavily debated. And if the Parliament would in majority say 'minister, we do not agree with this disbursement', then I have a major problem. So in fact there is a strong accountability certainly in my Parliament as in the German [one] as is in others. (European Parliament 2014c)

Indeed, the subject of democratic accountability of the Eurogroup and the ESM is a recurrent topic in the Economic Dialogues with Dijsselbloem. He has consistently defended his views that intergovernmental decision-making is completely democratic, while MEPs in turn have repeatedly followed up on their requests to increase the accountability of the Eurogroup to the EP. The gap between the structural weakness of national parliaments in the EU political system and the impossibility for the EP to make up for it - especially in relation to the ESM - is highlighted in the following exchange from 10 November 2015, in relation to a question on the rise of Euroscepticism in Europe:

Jeroen Dijsselbloem (Eurogroup Presidency, Netherlands): My opinion is that the issue of democratic legitimacy is more than a power struggle between institutions. If the European Parliament would have full competences in the field of the ESM and the programmes, I'm not sure that that would reduce the rise of Euroscepticism throughout Europe. I don't think it works that way. I know for a fact that the turnout for national elections in some countries is a lot higher than it is for European elections. I know for a fact that a lot of people in Europe feel more represented maybe by the local Council than they do by the national parliament, and more by the national parliament than they do by European institutions. So it's a bit more complex than that. 
Philippe Lamberts (Greend/EFA, Belgium): I'd like to take one example for that, because here Mr. Dijsselbloem you say that you are open to change the institutional framework that would make you more accountable here. Yet when I read your declaration in the Tweede Kamer [House of Representatives of Netherlands], well known to you, I read a completely different story. Or I see a rather different story where you say "well you know we do not want to go further in the direction of the community method, we are very happy with keeping things intergovernmental.' So the national context in the Netherlands, you sing a Dutch song, you come here you, sing a more European song. This is why, actually, we would like to have a stronger role here, and changing the institutions for that. So which Dijsselbloem do I have to believe?

The 'double hat' of the Eurogroup President - as representative of an EU institution and finance minister of his/her own country - is reflected in the suggestion of duplicity implied by Philippe Lamberts. Indeed, what prevents the Eurogroup President from saying one thing to the EP and another to a national parliament? A solution would be for the Eurogroup President to be a permanent EU official who stops acting as the finance minister of a Member State - in a similar vein to the President of the European Council. This, however, is not an option currently discussed in EMU reform circles.

Furthermore, in comparison to the Economic Dialogues with the ECOFIN Council Presidency, the 'European Semester' and 'fiscal consolidation' feature more frequently in meetings with the Eurogroup - in 112 out of 474 questions - which in relative terms is more than for ECOFIN. This is an interesting finding, keeping in mind that ECOFIN (and not the Eurogroup) is formally responsible for the European Semester - with the exception of the recommendations for the euro area. Another issue worth mentioning is 'domestic politics in the Presidency country', as Jeroen Dijsselbloem was sometimes questioned about the Netherlands (thirty-four times), for example, in relation to allegations that the country serves as a tax haven and should reform its tax laws (on twelve occasions). Otherwise, the Eurogroup President is also asked to comment on ECB monetary policy (twenty-four times), which is always a demand for policy views. Social aspects (twenty times) and investment (five times) are rarer than in Economic Dialogues with ECOFIN, although there are complaints about the ESM treatment of Greece and Cyprus, questioning the soundness of austerity policies or the fairness of 'bailin' measures (seventy times).

Overall, in terms of the relevance and intensity of the questions, the performance of MEPs is very strong - especially when compared to the 
other institutions analysed throughout the book (see Chapter 6.1). The next section turns towards the responsiveness of the Eurogroup President to questions asked during Economic Dialogues.

\subsubsection{Types of Answers Provided}

To what extent is the Eurogroup President open to answering questions from MEPs in the Economic Dialogues? Against common perceptions regarding its democratic accountability flaws, the Eurogroup has the best record of engaging with questions head-on, without trying to change the topic or obfuscate answers (Figure 6.15). Explicit replies rank the highest among all categories of questions identified, showing that on average the Eurogroup leadership does not try to avoid questions from MEPs. However, requests for policy change (type $\mathrm{C}$ ) are more likely to receive an intermediate or non-reply than other types of questions. In terms of the different Presidents, Dijsselbloem provides explicit replies in response to 66 per cent of all questions, Juncker in response to 60 per cent, and Centeno only in response to 30 per cent of all questions received. The period under investigation includes significantly different observations for the three Presidents because of the duration of their mandates (Juncker was present in one meeting, Centeno in two, and Dijsselbloem in eleven). Overall, Centeno is inclined to acknowledge questions and

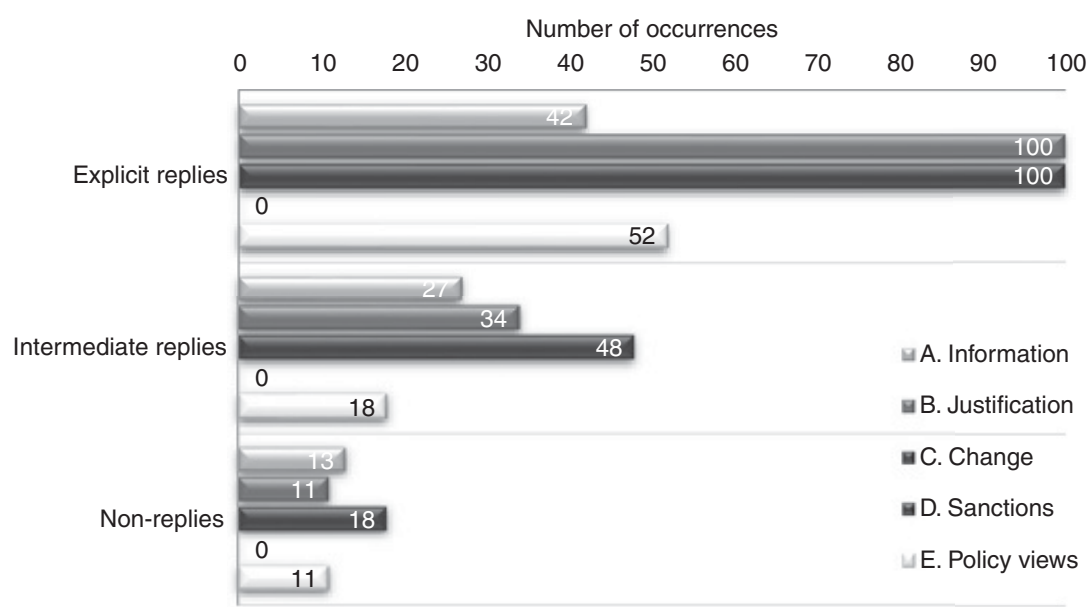

FIGURE 6.15 Types of answers provided by the Eurogroup President in Economic Dialogues at the EP (2013-2018). Total answers identified: 474 
speak about the topics covered in general terms, without giving details as mentioned in the questions of MEPs.

Next, how does the Eurogroup engage with MEPs during Economic Dialogues? Similar to the dynamics with ECOFIN, the majority of answers fall into the 'justification' category - meaning that the Eurogroup President addresses most questions by providing information, explaining the rationale for decisions, or defending the conduct of the institution (Figure 6.16). When taken together with answers giving policy views, the proportion of replies providing justification is 73 per cent of the 474 answers identified in the period under investigation. Such answers typically respond to transparency requests or classic 'why questions', demanding justification of past decisions (173). At the same time, there are numerous answers defending the Eurogroup's conduct and explaining why there can be no changes, for example, in respect of financial assistance programmes. One pertinent example comes from the Dialogue on 24 February 2015 - focused on the situation in Greece and the difficult negotiations with Prime Minister Alexis Tsipras and Finance Minister Yanis Varoufakis as the new interlocutors of the Greek government. At the time of the Dialogue, a 4-month delay had been agreed with the Syriza government on the fifth review of their second adjustment programme (which had been negotiated by the previous cabinet before elections). During the meeting, Dijsselbloem acknowledged the state of uncertainty but re-affirmed

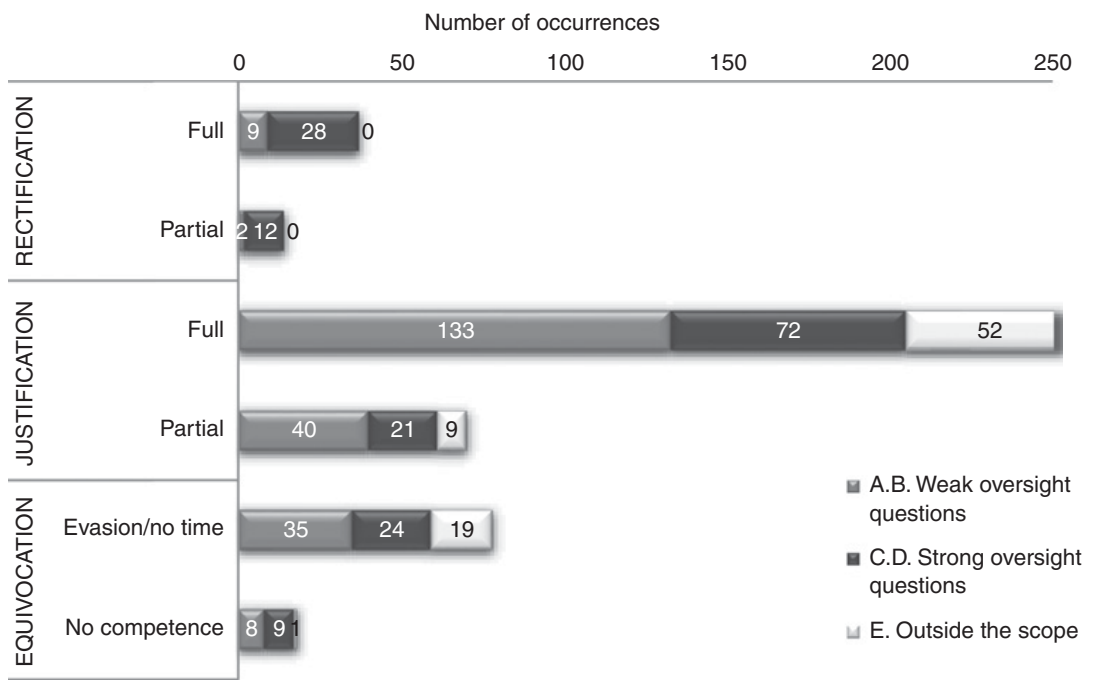

Figure 6.16 Degree of responsiveness by the Eurogroup President in Economic Dialogues (2013-2018) 
the intention to provide further financial assistance as long as Greece stuck to the conditions agreed. Some of exchanges were fierce, as illustrated below:

Marco Valli (EFDD, Italy): First of all, I would like to congratulate the President of the Eurogroup because I think what you have mentioned is incredible. A few weeks ago, we were facing a democratically elected government which had made promises to Greece and obviously that meant a 70 percent haircut to the debt. The end of the program they promised that and reimbursing war debts on the part of Germany. And just a few weeks ago that's what we heard and now we've got this result. So well done then for showing that we are really in a sort of technocratic dictatorship. I'm sure that's going to increase Euroscepticism and the consensus about people who don't believe in this Europe.

Jeroen Dijsselbloem (Eurogroup President, Netherlands): Let me first of all say something about the democratic process and promises made to electorates. I think the outcome of the Greek election was a clear signal from the Greek electorate. But in the Eurogroup we have to deal with 19 ministers who have 19 mandates from 19 electorates. And if there is reason for further support for one specific country it has to be on a joint agreement and therefore 19 mandates are to be taken in consideration. You may not find that democratic but I do. Ministers have to go back to their Parliaments and have to get support in their parliaments for further support, in this case Greece. So it's not just about the choice of the Greek electorate, which we have to respect and I'm sure that the new Greek government will put their stamp on the programme as we know it given the flexibility that we have. But you are mistaken if you think democracy is that one election results can change the way we work in the Eurozone or in the European Union. That will be a very strange interpretation of democracy. (European Parliament 2015b)

Answers to demands for policy views are also included under justification (61 times), although they are not a traditional accountability instrument. As part of the interinstitutional relationship between the Eurogroup and the EP, questions for policy views are most of the time 'easy' to answer - although they can occasionally touch upon controversial policy issues.

In Figure 6.16, the next category is made of equivocated answers ( 16 per cent overall) - including 5 per cent generic replies, that is, answers that acknowledge the topic of a question but discuss the subject in broad terms, without referring to the specific issues raised by MEPs. One interesting example comes from the regular Dialogue on 10 November 2015, when Dijsselbloem is asked by Jonás Fernández (S\&D, Spain) whether he is ready to sign an 
interinstitutional agreement in which he 'agrees to answer written questions from MEPs' in order to show 'the democratic legitimacy of the European Union'. The answer is evaded, as the minister does not mention the prospect of answering written questions at all:

Jeroen Dijsselbloem (Eurogroup President, Netherlands): The inter-institutional agreement, as mentioned in the Five Presidents' Report, had a different function. It was about involving the Parliament at the beginning of the Semester and at the end of the Semester and having a debate also on the euro area recommendations - the euro area stance before the CSRs etc. are designed. That's how I understand what we had outlined in the Five Presidents' Report and I hope that the Commission will pick that idea up. (European Parliament 2015c)

Finally, there are answers in which the Eurogroup President recognises that mistakes were made in the past or, alternatively, that there is a need for a change of approach on a given issue (11 per cent of the total, Figure 6.16). It is worth noting that Eurogroup Presidents acknowledge errors at times: for example, Dijsselbloem has repeatedly taken responsibility for the decisions regarding Cyprus in March-April 2013 - especially when it came to the controversial decision of 'bailing in' all depositors (including those with less than 100,000 euros) in order to 'bail out' the banking system. In this particular instance, MEPs insisted to know which governments supported the move, but Dijsselbloem refused to reveal internal Eurogroup dynamics, arguing that the Council takes decisions as a whole and it does not matter who supported what during the negotiations. This is consistent wih Puetter's accounts of informal working methods in the Eurogroup, focused on secret deliberations and consensus decision-making (Puetter 2004, 2006, 2016). It also suggests that the Eurogroup President is an appropriate interlocutor for the EP in accountability exchanges; so far, the person holding the office of Eurogroup President has consistently been able to speak on behalf of the nineteen Eurozone Member States.

\subsubsection{Summary}

On the whole, the Economic Dialogues with the Eurogroup President are probably the most targeted and straightforward oversight interactions in the ECON Committee. Given the high profile of the Eurogroup in the EMU, MEPs were interested in asking questions about financial assistance, upcoming Eurozone reforms, or sensitive issues in the European Semester such as the EDP. The period under focus has also covered some of the most 
controversial episodes in the euro crisis - including the ESM programmes for Cyprus in 2013 and Greece in 2015. The media paid attention to such Economic Dialogues and MEPs asked a lot of questions about ongoing negotiations and decisions taken. In 2018, as the Eurozone was back to economic growth and Mario Centeno took over the Eurogroup Presidency, MEPs seemed less antagonistic towards the intergovernmental body. But given the lack of formal control the EP has over the Eurogroup and the ESM, it is not surprising that MEPs have consistently complained about the democratic accountability credentials of the institution. What is surprising is the answerability of the Eurogroup President in response to oral questions by MEPs. Given the notorious secrecy of the institution, we would have expected less engagement with parliamentary questions. While this responsiveness might be related to the personal style of Jeroen Dijsselbloem - who served as Eurogroup President for five years - it is a positive finding that the majority of questions identified were explicit replies. Judging by the answers, it is clear that the Eurogroup has a specific understanding of its accountability obligations to the EP, namely it stands ready to describe and explain its decisions (justification) but not change them (rectification). The dynamic also reveals the ultimate accountability flaw of EMU intergovernmental bodies, whose collective decisions can be scrutinised but not controlled in the EU political system.

\subsection{THE RECORD: HOLDING FINANCE MINISTERS ACCOUNTABLE IN THE EMU}

Drawing on the analysis above, it is possible to make an assessment of the type of legislative oversight scenario that fits the Economic Dialogues with the ECOFIN Council and the Eurogroup. In line with Chapter 3.3.1, the choices are based on a continuum from 'High control' by the EP (oversight scenario 1) to 'No control' (scenario 6). Depending on the strength of questions asked and the corresponding responsiveness of executive actors, the continuum further includes the possibility for 'Answerability' (scenario 2), 'Voluntary accountability' (scenario 3), 'Transparency' (scenario 4), and 'Drift' (scenario 5). Bearing in mind the EU Treaty framework and the representative roles of the EP and the Council thereof, the relationship between the two institutions can be compared to legislative-executive interactions in a presidential system - where the legislature is not the principal of the executive and both actors have a direct mandate from citizens. In this respect, the best-case scenario of oversight interactions expected between the EP and ECOFIN/the Eurogroup was 'Answerability' (see Chapter 3.3.2). 
Furthermore, as illustrated in the analytical framework (Figure 3.2), there were additional variables considered such as the extent of public pressure on key oversight topics and structural opportunities for parliamentary scrutiny, which were expected to have positive effects on accountability interactions. By contrast, other variables were seen to have negative effects on oversight, namely the profile of the EP as a law-making parliament and its multi-party system, the asymmetry of information between the EP and executive bodies, and the difficulty to disentangle collective decision-making in intergovernmental bodies. In the analysis presented in this chapter, some variables turned out to be similar in the EP's relationship with ECOFIN and the Eurogroup: for instance, structural opportunities for oversight are limited to oral questions in committee meetings for both executive bodies, albeit the ECOFIN Council Presidency comes to the ECON Committee more often than the Eurogroup President. At the same time, it is equally difficult to disentangle collective decision-making in the ECOFIN Council and the Eurogroup, as ministers do not disclose the positions of individual Member States in intergovernmental negotiations.

However, there are also important differences between the variables of the analytical framework reflected in the EP's oversight interactions with ECOFIN and the Eurogroup. Most crucially, public attention to Economic Dialogues varies significantly, as the media covers meetings with the Eurogroup President much closer than encounters with the ECOFIN Council Presidency. In terms of parliamentary questions, this is visible in the types of questions asked to the Eurogroup (which focus on financial assistance programmes, future Eurozone reforms, or European Semester decisions) and the high number of follow-up questions identified across political groups and nationalities of MEPs. In other words, high public pressure on specific EMU issues outweighs other variables such as the profile of the EP as a law-making parliament and its multi-party system. Conversely, in the relationship with the ECOFIN Council, where media attention and public pressure are generally low, parliamentary questions reflect much closer the emphasis of the EP on law-making and its multi-party, multi-national system. This is illustrated by the high number of questions regarding legislative dossiers and the low number of follow-up questions addressed to ECOFIN ministers (as opposed to the Eurogroup President). Last but not least, when it comes to the asymmetry of information between the EP and the ECOFIN Council/the Eurogroup, it was expected that the Eurogroup would perform worse than ECOFIN due to its informal and secretive proceedings (Craig 2017; Puetter 2006). In practice, however, the Eurogroup provided more explicit replies and less equivocations than ECOFIN in the period under focus, showing a higher readiness to engage with substantive 
oversight questions from MEPs. Nevertheless, this record could just be owed to the personal style of Jeroen Dijsselbloem, who tended to give direct and frank answers in response to parliamentary questions.

Taking all this into consideration and in line with the expectations of different oversight scenarios (Chapter 3.3.1), the Economic Dialogues with the ECOFIN Council are considered an example of 'Transparency' (scenario 4), with some elements of 'No control' (scenario 6) - given the focus on legislative negotiations (ex ante policy-making as opposed to ex post accountability). The assessment takes into account the proportion of weaker oversight questions ( 283 in total), which is slightly higher than stronger oversight questions (219 in total) but with more requests for information than justification of conduct. In turn, the ECOFIN Council answers the majority of questions through justification: either in full (273 times) or partially (123 times). In addition, a relatively high number of replies are equivocations based on generic answers or dodged questions (130 in total). Given this record, both MEPs and the ECOFIN Council Presidency could do more to improve their accountability interactions, as discussed in the next chapter.

For its part, the Eurogroup President also receives weaker oversight questions (227 times) more frequently than stronger oversight questions (166 times). Nonetheless, the topic of questions is much more relevant for the parliamentary scrutiny of an executive actor than the questions addressed to ECOFIN. In the Economic Dialogues with the Eurogroup, MEPs actually inquire about the past activities and specific decisions of the institution in the ESM or the European Semester. By contrast, the Economic Dialogues with ECOFIN revolve around legislative negotiations and are thus less a case of parliamentary scrutiny of the executive as they are an example of interactions between co-legislators in a bicameral political system. Moreover, the general responsiveness of the Eurogroup President - answering more than half of the questions through full justification - puts this type of Economic Dialogue in the 'Answerability' scenario of legislative oversight (see Chapter 3.3.1, scenario 2). In other words, the EP has no control over Eurogroup decisions, but it can successfully scrutinise its actions ex post by demanding transparency and justification of conduct. The next chapter situates this record in relation to the oversight interactions examined in the book. 